\title{
RADIOACTIVE SEMIVOLATILES IN NUCLEAR FUEL REPROCESSING
}

R. T. Jubin, D. M. Strachan, G. llas, B. B. Spencer, N. R. Soelberg

September 2014

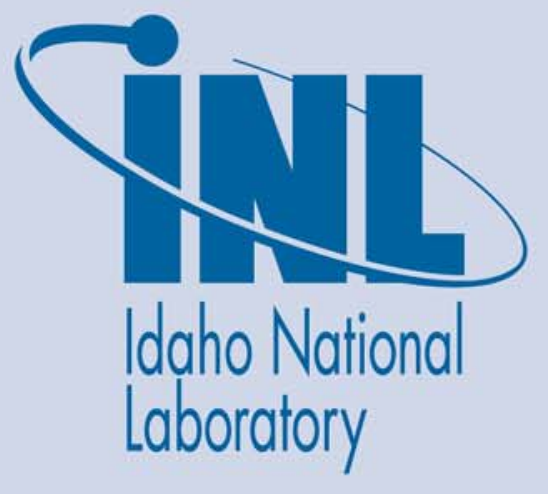

The INL is a U.S. Department of Energy National Laboratory operated by Battelle Energy Alliance 


\title{
RADIOACTIVE SEMIVOLATILES IN NUCLEAR FUEL REPROCESSING
}

\author{
R. T. Jubin, D. M. Strachan, G. llas, B. B. Spencer, N. R. Soelberg
}

September 2014

\author{
Idaho National Laboratory \\ Idaho Falls, Idaho 83415
}

http://www.inl.gov

Prepared for the

U.S. Department of Energy

Office of Nuclear Energy

Under DOE Idaho Operations Office

Contract DE-AC07-05ID14517 
Radioactive

Semivolatiles in Nuclear

Fuel Reprocessing

Fuel Cycle Research \& Development

Prepared for

U.S. Department of Energy

R. T. Jubin, D. M. Strachan*, G. Ilas,

B. B. Spencer, and N. R. Soelberg ${ }^{t}$ Oak Ridge National Laboratory,

*Pacific Northwest National Laboratory

(Retired) and 'Idaho National

Laboratory

12 September 2014

FCRD-SWF-2014-000601

ORNL/LTR-2014/354 



\section{DISCLAIMER}

This information was prepared as an account of work sponsored by an agency of the U.S. Government. Neither the U.S. Government nor any agency thereof, nor any of their employees, makes any warranty, expressed or implied, or assumes any legal liability or responsibility for the accuracy, completeness, or usefulness, of any information, apparatus, product, or process disclosed, or represents that its use would not infringe privately owned rights. References herein to any specific commercial product, process, or service by trade name, trade mark, manufacturer, or otherwise, does not necessarily constitute or imply its endorsement, recommendation, or favoring by the U.S. Government or any agency thereof. The views and opinions of authors expressed herein do not necessarily state or reflect those of the U.S. Government or any agency thereof. 



\section{SUMMARY}

In nuclear fuel reprocessing, various radioactive elements enter the gas phase from the unit operations found in the reprocessing facility. In previous reports, the pathways and required removal of four radionuclides known to be volatile, ${ }^{14} \mathrm{C},{ }^{3} \mathrm{H},{ }^{129} \mathrm{I}$, and ${ }^{85} \mathrm{Kr}$, were discussed. Other less volatile isotopes can also report to the off-gas streams in a reprocessing facility. In this report, an effort is made to determine which, if any, of 24 semivolatile radionuclides could be released from a reprocessing plant and, if so, what would be the likely quantities released. As part of this study of semivolatile elements, the amount of each generated during fission is included as part of the assessment for the purpose of controlling their emission. Also included in this study is an assessment of the cooling time (time out of reactor) before the fuel is processed. This aspect is particularly relevant to the short-lived isotopes, especially for cooling times approaching 10 years.

The objective of this study was to determine if semivolatile radionuclides need to be included in a list of gas-phase radionuclides for possible removal to meet Environmental Protection Agency (EPA) and Nuclear Regulatory Commission (NRC) regulations. A list of potential elements was developed based on a literature search and knowledge of the chemical processes in typical aqueous processing of nuclear fuels. A long list of possible radionuclides present in irradiated fuel was generated and then trimmed by considering isotope half-life and calculating the dose from each to a maximum exposed individual using the US EPA airborne radiological dispersion and risk assessment code CAP88 (Rosnick 1992). Control of the elements included on the shorter list needs to be considered because they require high decontamination factors to meet a reasonable fraction of the regulated release. Each of these elements is discussed with respect to what is known in the literature about its behavior in a reprocessing facility.

A $\mathrm{UO}_{2}$-based fuel processed through an aqueous-based reprocessing system with a tributyl phosphatebased solvent extraction chemistry was used in this evaluation. None of the elements form sufficiently volatile compounds, in the context of the reprocessing facility, to be of regulatory concern from an emission standpoint based on volatility alone and with current or proposed use of scrubbers and particulate filtration technology. 


\section{CONTENTS}

SUMMARY iii

FIGURES $\mathrm{V}$

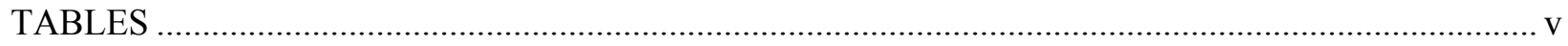

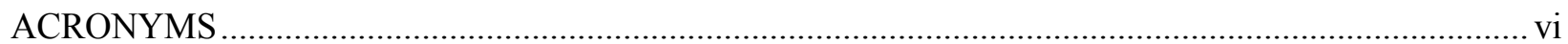

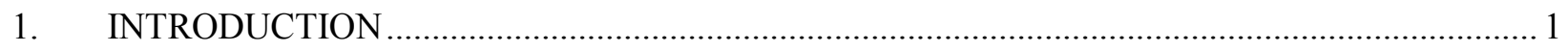

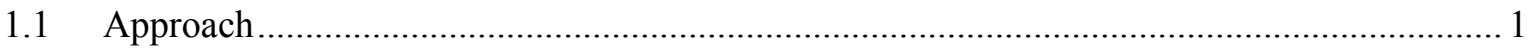

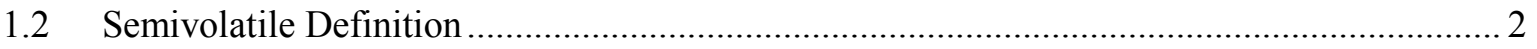

2. EXPECTED INVENTORIES FOR POTENTIAL SEMIVOLATILE ISOTOPES .......................... 3

3. POTENTIAL REQUIRED DECONTAMINATION FACTORS …............................................. 3

4. CHEMISTRY OF THE ELEMENTS POTENTIALLY REQUIRING CONTROL ....................... 6

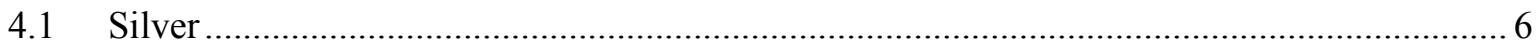

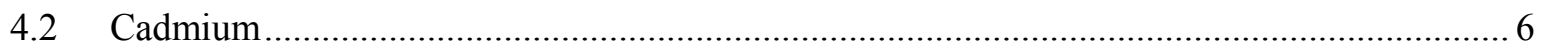

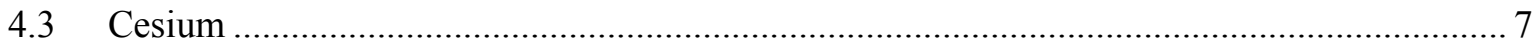

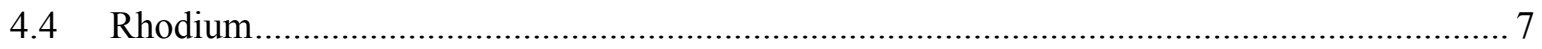

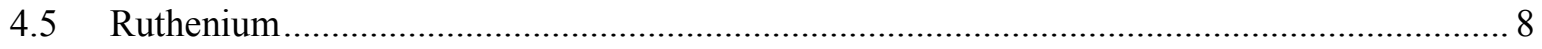

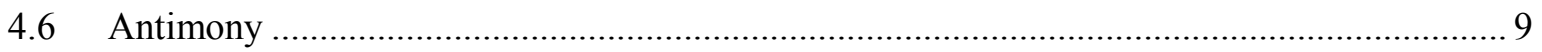

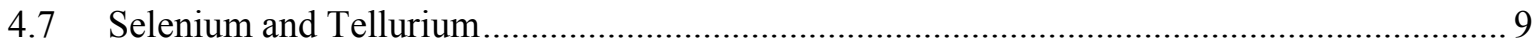

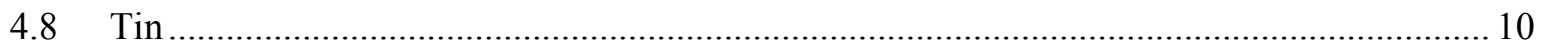

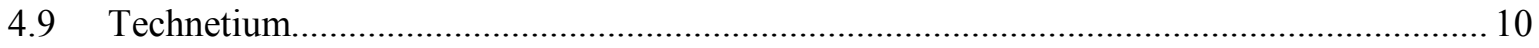

4.10 A General Source of Radionuclides in the Off-Gas - Aerosols and Particulates .................. 11

5. ASSESSMENT OF THE IMPACT OF SEMIVOLATILES IN A REPROCESSING

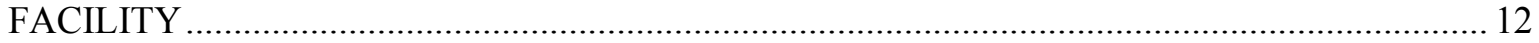

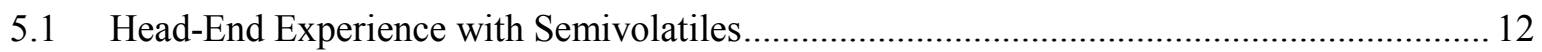

5.1.1 Air/Oxygen Low-Temperature $\left(480-600^{\circ} \mathrm{C}\right)$ Tritium Pretreatment......................... 12

5.1.2 Advanced Tritium Pretreatment at Low Temperatures $\left(250-400^{\circ} \mathrm{C}\right) \ldots \ldots \ldots \ldots \ldots \ldots \ldots \ldots . . . . . . . . .14$

5.1.3 High-Temperature $\left(>900^{\circ} \mathrm{C}\right)$ Pretreatment Associated with the Direct Use of Spent PWR Fuel In CANDU (DUPIC) and Accident Conditions ........................... 15

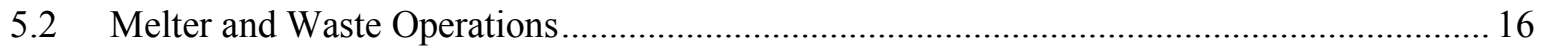

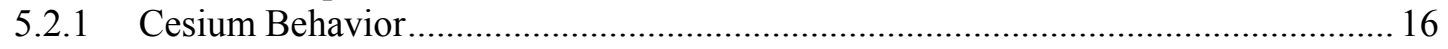

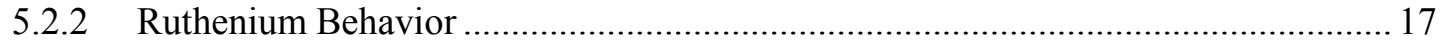

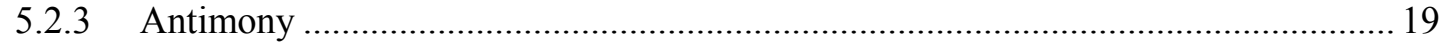

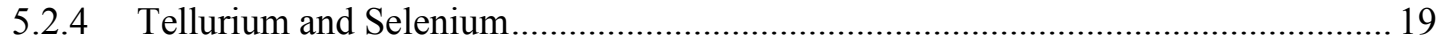

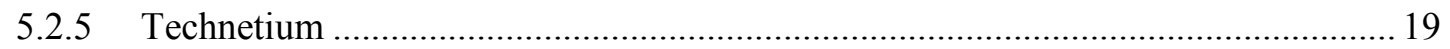

5.2.6 Comparison of Releases between CCIM and JHMM ............................................ 19

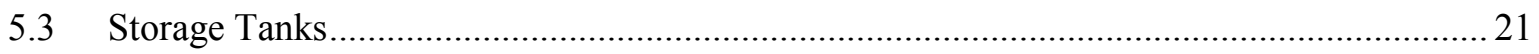

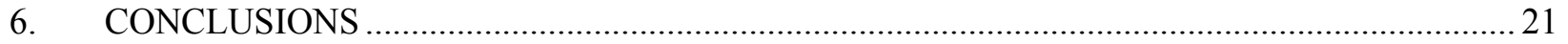

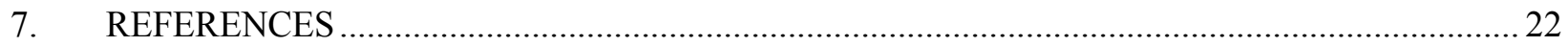




\section{FIGURES}

Figure 5-1. Predominance diagram for Ru-O-N system: dioxide and tetraoxide equilibria...................... 13

Figure 5-2. Predominance diagram for Ru-O-N system: metal and dioxide equilibria. ........................... 14

Figure 5-3. Melter partitioning data from a pilot-scale CCIM test for DWPF Sludge Batch 4 surrogate feed (Soelberg 2009).

\section{TABLES}

Table 1-1. Potentially semivolatile isotopes with half-lives greater than 91 days considered in this study

Table 3-1. Results for the radioactivity in $1 \mathrm{t}$ of UNF with 60-GWd/tIHM burnup from ORIGEN calculations for the list of radionuclides shown in Table 1-1 for a 5-year cooling time. Isotopes with no entry had no output from ORIGEN; not a zero value

Table 3-2. Doses from the isotopes and associated releases shown in Table 3-1

Table 3-3. Maximum required DFs for the isotopes shown in Table 3-2 for each isotope to yield $0.025 \mathrm{mRem}$ to the MEI. Only isotopes requiring a DF $>1$ for the $1000 \mathrm{tIHM} / \mathrm{y}$ case are shown

Table 4-1. Aerosol contributions to the vessel off-gas from vessels in the first cycle solvent extraction system (Herrmann et al. 1980).....

Table 5-1. Design and measured cesium decontamination factors (Zamecnik et al. 1992)...................... 17

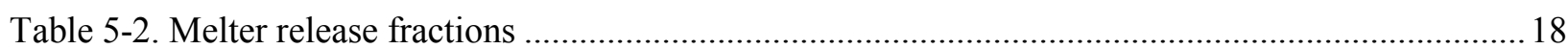

Table 5-3. Melter DFs for selected semi-volatile species (Gruber et. al. 2011) ........................................ 20 


\section{ACRONYMS}

CCIM cold crucible induction melter

CEA Commissariat à l'énergie atomique

CETE coupled end-to-end

CFR Code of Federal Regulations

$\mathrm{Ci} \quad$ curies

DF decontamination factor

DOE U.S. Department of Energy

EPA U.S. Environmental Protection Agency

DUPIC Direct Use of spent PWR fuel In CANDU

DWPF Defense Waste Processing Facility

GW gigawatt $\left(10^{9} \mathrm{~W}\right)$

GWd gigawatt-days

GWy gigawatt-year

$\mathrm{GWd} / \mathrm{t} \quad$ gigawatt-day per tonne (metric ton)

HEPA High Efficiency Particulate Air

HLW high-level waste

HWIM hot-wall induction melter

HWRM hot-wall resistance melter

IAEA International Atomic Energy Agency

ICM in-canister melter

IDMS Integrated DWPF Melter System

IHM initial heavy metal (mass of fuel before irradiation)

INL Idaho National Laboratory

JHMM Joule-heated metal melter

KAERI Korean Atomic Energy Research Institute

LEU low-enriched uranium (enrichment with respect to ${ }^{235} \mathrm{U}$ )

LFCM Liquid-fed ceramic melter

MEI maximum exposed individual 
Radioactive Semivolatiles in Nuclear Fuel Reprocessing

September 2014

vii

$\begin{array}{ll}\text { mRem } & \text { millirem } \\ \text { MW } & \text { megawatt }\left(10^{6} \mathrm{~W}\right) \\ \text { MWd } & \text { megawatt-days } \\ \text { NRC } & \text { U.S. Nuclear Regulatory Commission } \\ \text { ORNL } & \text { Oak Ridge National Laboratory } \\ \text { PWR } & \text { pressurized water reactor } \\ \text { scfm } & \text { standard cubic feet per minute } \\ \text { t } & \text { tonne (metric ton or } 1000 \mathrm{~kg}) \\ \text { TBP } & \text { tributyl phosphate } \\ \text { UNF } & \text { used nuclear fuel } \\ \text { WSEP } & \text { Waste Solidification Engineering Prototypes }\end{array}$





\section{RADIOACTIVE SEMIVOLATILES IN NUCLEAR FUEL REPROCESSING}

\section{INTRODUCTION}

In nuclear fuel reprocessing, various radioactive elements enter the gas phase across the range of unit operations found in the reprocessing facility. Jubin et al. (2012a, 2012b) reported on the pathways and required removal of four radionuclides known to be volatile, ${ }^{14} \mathrm{C},{ }^{3} \mathrm{H},{ }^{129} \mathrm{I}$, and ${ }^{85} \mathrm{Kr}$. Other less volatile isotopes such as $\mathrm{Cs}, \mathrm{Cd}, \mathrm{Ru}, \mathrm{Sb}, \mathrm{Tc}$, and Te can also report to the off-gas streams in a reprocessing facility, as described by Klein (1991).

A study has been performed to determine if radionuclides present in used fuel, which are or can form compounds known to be semivolatile during used fuel reprocessing, need to be captured along with volatile radionuclides in reprocessing facility off-gas systems, to ensure compliance to Environmental Protection Agency (EPA) and Nuclear Regulatory Commission (NRC) regulations. This is a follow-on study to the volatile radionuclide evaluations reported by Jubin et al. (2012a, 2012b).

\subsection{Approach}

This study was performed in several steps.

- A list of possible isotopes was generated with the ORIGEN and SCALE codes (Gauld et al. 2011, ORNL 2009).

- A list of possible semivolatile compounds containing these isotopes was developed based on a literature search and knowledge of the chemical processes in typical aqueous processing of nuclear fuels, assuming initially that all elements (isotopes) that can form volatile species through chemical reaction do form those volatile species. Electrochemical used fuel reprocessing was not included in the scope of this study.

- This long list of possible radionuclides was shortened by considering only isotopes with half-lives greater than 91 days, since isotopes with half-lives shorter than 91 days would decay to negligible levels (by a factor of $9.5 \times 10^{-7}$ ) if used fuel is not reprocessed for at least 5 years after removal from the reactor.

- This list of isotopes was further trimmed by calculating the dose from each to a maximum exposed individual (MEI) with the US EPA airborne radiological dispersion and risk assessment code CAP-88 (Rosnick 1992) to yield a shorter list. Control of the elements on this list needs to be considered because they could require high decontamination factors (DFs, the ratio of the uncontrolled and controlled emission) to meet a reasonable fraction of the regulated release.

- Each of these isotopes was then discussed with respect to what is known in the literature about their behavior in a reprocessing facility.

The isotopes of interest are shown in Table 1-1. Of these, cesium has been treated successfully for many years. Removal of technetium has also been studied as part of the development of nuclear waste treatment facilities such as West Valley, the Savannah River Plant, and Hanford.

While ${ }^{130}$ Te and ${ }^{115}$ In are significant naturally occurring isotopes, about $34 \%$ and $96 \%$, respectively, of the naturally occurring elements, their release to the environment during the processing of UNF requires potential controls since they are generated as fission products. As part of this study of semivolatile 
elements, the amount of each generated during fission is included in order to assess the need for emission control. Also considered in this study is cooling time (time out of reactor) before the fuel is processed.

Table 1-1. Potentially semivolatile isotopes with half-lives greater than 91 days considered in this study

\begin{tabular}{|c|c|c|c|}
\hline Isotope & Half-Life & Isotope & Half-Life \\
\hline${ }^{110 \mathrm{~m}} \mathrm{Ag}$ & 249.8 days & ${ }^{184 \mathrm{~m}} \mathrm{Re}$ & 165 days \\
\hline${ }^{195} \mathrm{Au}$ & 186.1 days & ${ }^{187} \mathrm{Re}$ & $4.1 \times 10^{10}$ years \\
\hline${ }^{207} \mathrm{Bi}$ & 32.2 years & ${ }^{101} \mathrm{Rh}$ & 3.3 years \\
\hline${ }^{208} \mathrm{Bi}$ & $3.68 \times 10^{5}$ years & ${ }^{102} \mathrm{Rh}$ & 2.9 years \\
\hline${ }^{210 \mathrm{~m}} \mathrm{Bi}$ & $3.0 \times 10^{6}$ years & ${ }^{102 \mathrm{~m}} \mathrm{Rh}$ & 207 days \\
\hline${ }^{109} \mathrm{Cd}$ & 462 days & ${ }^{106} \mathrm{Ru}$ & 1.02 years \\
\hline${ }^{113} \mathrm{Cd}$ & $9 \times 10^{15}$ years & ${ }^{125} \mathrm{Sb}$ & 2.76 years \\
\hline${ }^{113 \mathrm{~m}} \mathrm{Cd}$ & 14.1 years & ${ }^{75} \mathrm{Se}$ & 120 days \\
\hline${ }^{134} \mathrm{Cs}$ & 2.065 years & ${ }^{79} \mathrm{Se}$ & $6.5 \times 10^{4}$ years \\
\hline${ }^{135} \mathrm{Cs}$ & $2.3 \times 10^{6}$ years & ${ }^{113} \mathrm{Sn}$ & 115.1 days \\
\hline${ }^{137} \mathrm{Cs}$ & 30.17 years & ${ }^{119 m} \mathrm{Sn}$ & 293 days \\
\hline${ }^{68} \mathrm{Ge}$ & 270.8 days & ${ }^{121 \mathrm{~m}} \mathrm{Sn}$ & 55 years \\
\hline${ }^{115} \mathrm{In}$ & $4.4 \times 10^{14}$ years & ${ }^{123} \mathrm{Sn}$ & 129.2 days \\
\hline${ }^{40} \mathrm{~K}$ & $1.25 \times 10^{9}$ years & ${ }^{97} \mathrm{Tc}$ & $2.6 \times 10^{6}$ years \\
\hline${ }^{22} \mathrm{Na}$ & 2.60 years & ${ }^{98} \mathrm{Tc}$ & $4.2 \times 10^{6}$ years \\
\hline${ }^{202} \mathrm{~Pb}$ & $5.3 \times 10^{4}$ years & ${ }^{99} \mathrm{Tc}$ & $2.13 \times 10^{5}$ years \\
\hline${ }^{205} \mathrm{~Pb}$ & $1.5 \times 10^{7}$ years & ${ }^{121 \mathrm{~m}} \mathrm{Te}$ & 154 days \\
\hline${ }^{107} \mathrm{Pd}$ & $6.5 \times 10^{6}$ years & ${ }^{123} \mathrm{Te}$ & $1.3 \times 10^{13}$ years \\
\hline${ }^{208} \mathrm{Po}$ & 2.898 years & ${ }^{123 \mathrm{~m}} \mathrm{Te}$ & 120 days \\
\hline${ }^{209} \mathrm{Po}$ & 102 years & ${ }^{127 \mathrm{~m}} \mathrm{Te}$ & 109 days \\
\hline${ }^{210} \mathrm{Po}$ & 138.4 days & ${ }^{130} \mathrm{Te}$ & $2.5 \times 10^{21}$ years \\
\hline${ }^{190} \mathrm{Pt}$ & $6 \times 10^{11}$ years & ${ }^{204} \mathrm{Tl}$ & 3.78 years \\
\hline${ }^{83} \mathrm{Rb}$ & 86.2 days & ${ }^{65} \mathrm{Zn}$ & 243.8 days \\
\hline${ }^{87} \mathrm{Rb}$ & $4.8 \times 10^{10}$ years & & \\
\hline
\end{tabular}

This aspect is important for the short-lived isotopes shown in the list, especially for cooling times approaching 10 years.

\subsection{Semivolatile Definition}

Jubin et al. (2012a, 2012b) reported on recognizable volatile elements forming known volatile or gaseous species associated with the reprocessing of nuclear fuels. They exist as gases at ambient conditions, or they have very high vapor pressures so that they readily volatilize. There is, however, another group of elements with reaction products that, if formed, would be expected to be at least somewhat volatile, or semivolatile, under certain conditions and need to be removed from the off-gas streams. The term semivolatile does not appear to be concisely defined in the literature. The EPA defines a semivolatile organic compound as "an organic compound which has a boiling point higher than water and which may vaporize when exposed to temperatures above room temperature" but fails to provide a specific standalone definition of the descriptor "semivolatile" (http://www.epa.gov/reg3hwmd/bf-lr/regional/analytical 
/semi-volatile.htm). Even a quick search of the literature and Wikipedia did not result in a concise definition. In this study, the term semivolatile is used to identify inorganic and organometallic species that are gaseous at ambient conditions within a reprocessing facility or have sufficiently high vapor pressures to report to the vapor phase above process liquids. Generally, the metal elements are not volatile and only become volatile when they react with other elements and form compounds that are volatile.

In a recent International Atomic Energy Agency (IAEA) report (IAEA 2014), these radionuclides are given the description "Potentially Volatile." This list is shorter than the list shown in Table 1-1. Goles et al. (1981) "defined" ${ }^{78} \mathrm{Se},{ }^{99} \mathrm{Tc},{ }^{106} \mathrm{Ru},{ }^{125,126} \mathrm{Sb},{ }^{125 \mathrm{~m}} \mathrm{Te}$, and ${ }^{134,135,137} \mathrm{Cs}$ as semivolatile isotopes (elements).

\section{EXPECTED INVENTORIES FOR POTENTIAL SEMIVOLATILE ISOTOPES}

An ORIGEN calculation was performed to generate radionuclide inventories for the isotopes shown in Table 1-1. The results are for a pressurized water reactor (PWR) containing low-enriched uranium (LEU) fuel that was irradiated to a burnup of $60 \mathrm{GWd} / \mathrm{tIHM}$. The isotopic content, radioactivity, and residual decay heat data were obtained by performing depletion and decay simulations with the ORIGEN code in SCALE (Gauld et al. 2011, ORNL 2009). The burnup-dependent cross section libraries used in the ORIGEN simulations were generated using TRITON (DeHart and Bowman 2011).

Radionuclide inventories, radioactivity, and decay heat data were generated for cooling times after fuel discharge from the reactor of 0 (discharge), 1, 2, 5, 10, 20, 30, 50, 70, and 100 years. Only 5-year cooling was used in this report (Table 3-1). In Table 3-1, some isotope inventories are not reported as they did not appear in the output list from ORIGEN and SCALE.

\section{POTENTIAL REQUIRED DECONTAMINATION FACTORS}

Not all the isotopes shown in Table 3-1 result in negligible dose consequences. To understand the required DF for each of the semivolatile elements, the maximum dose was calculated by assuming that $100 \%$ of each isotope shown in Table 3-1 is released into reprocessing facility off-gas. This is, of course, a very conservative case because the entire mass of each isotope may not evolve to the off-gas. The CAP88 code (Rosnick 1992) version 4 for the personal computer was used to calculate the dose to the MEI. The Idaho site was used as the basis for the meteorological conditions, and the effluent was released through a $100-\mathrm{m}$ tall stack. Other locations could also have been used, but prior studies that compared results from different locations have shown that use of multiple locations was not needed to meet the objectives of this study (Jubin et al. 2012b, Jubin et al. 2012a). The calculation yielded an MEI at $400 \mathrm{~m}$ north-northeast from the stack. Each isotope concentration was input to the code to calculate the exposure. Two dose values were calculated: one for the processing of used fuel at a rate of 1 tonne initial heavy metal per year (tIHM/year) and one for a facility in which $1000 \mathrm{tIHM} /$ year were processed. Since the regulation is based on an annual dose, the second value was used to calculate the maximum DF required for each isotope.

The maximum yearly dose put forth in 40 CFR 190 (EPA 2010) is $25 \mathrm{mRem}$. In their work on the volatile elements of ${ }^{14} \mathrm{C},{ }^{3} \mathrm{H},{ }^{129} \mathrm{I}$, and ${ }^{85} \mathrm{Kr}$, Jubin et al. (2012a, 2012b) considered two cases-one in which all isotopes contributed to the full $25-\mathrm{mRem} /$ year limit and one in which $2.5 \mathrm{mRem} /$ year (10\%) was ascribed to the volatiles. Similarly in this semivolatile study, a smaller fraction of the overall limit was used to calculate the required DF for each radionuclide. The value selected was $0.025 \mathrm{mRem} /$ year $(0.1 \%$ of the $25-\mathrm{mRem} /$ year regulatory limit). The assumption here was that the major fraction of the allowable 
emissions would be taken by the alpha emitters and the four volatile isotopes. This represented a very conservative case in that the low dose allocation requires a higher DF.

Table 3-1. Results for the radioactivity in $1 \mathrm{t}$ of UNF with 60-GWd/tIHM burnup from ORIGEN calculations for the list of radionuclides shown in Table 1-1 for a 5-year cooling time. Isotopes with no entry had no output from ORIGEN; not a zero value

\begin{tabular}{|c|l|r|l|}
\hline Isotope & \multicolumn{1}{|c|}{ Curies } & Isotope & \multicolumn{1}{|c|}{ Curies } \\
\hline${ }^{110 \mathrm{~m}} \mathrm{Ag}$ & 0.675 & ${ }^{184 \mathrm{~m}} \mathrm{Re}$ & \\
${ }^{195} \mathrm{Au}$ & & ${ }^{187} \mathrm{Re}$ & \\
${ }^{207} \mathrm{Bi}$ & $1.55 \times 10^{-15}$ & ${ }^{101} \mathrm{Rh}$ & $1.68 \times 10^{-4}$ \\
${ }^{208} \mathrm{Bi}$ & $1.99 \times 10^{-16}$ & ${ }^{102} \mathrm{Rh}$ & 0.0240 \\
${ }^{210 \mathrm{~m}} \mathrm{Bi}$ & $3.86 \times 10^{-17}$ & ${ }^{102 \mathrm{~m}} \mathrm{Rh}$ & 0.672 \\
${ }^{109} \mathrm{Cd}$ & 0.0369 & ${ }^{106} \mathrm{Ru}$ & $3.19 \times 10^{4}$ \\
${ }^{113} \mathrm{Cd}$ & $6.04 \times 10^{-14}$ & ${ }^{125} \mathrm{Sb}$ & $4.53 \times 10^{3}$ \\
${ }^{113 \mathrm{~m}} \mathrm{Cd}$ & 0.348 & ${ }^{75} \mathrm{Se}$ & $1.69 \times 10^{-8}$ \\
${ }^{134} \mathrm{Cs}$ & $7.53 \times 10^{4}$ & ${ }^{79} \mathrm{Se}$ & 0.118 \\
${ }^{135} \mathrm{Cs}$ & 0.753 & ${ }^{113} \mathrm{Sn}$ & $3.60 \times 10^{-11}$ \\
${ }^{137} \mathrm{Cs}$ & $1.68 \times 10^{5}$ & ${ }^{119 m} \mathrm{Sn}$ & 1.30 \\
${ }^{68} \mathrm{Ge}$ & $2.45 \times 10^{-16}$ & ${ }^{121 \mathrm{~m}} \mathrm{Sn}$ & 25.9 \\
${ }^{115} \mathrm{In}$ & $1.80 \times 10^{-11}$ & ${ }^{123} \mathrm{Sn}$ & 0.342 \\
${ }^{40} \mathrm{~K}$ & $5.69 \times 10^{-7}$ & ${ }^{97} \mathrm{Tc}$ & $1.79 \times 10^{-8}$ \\
${ }^{22} \mathrm{Na}$ & $1.36 \times 10^{-8}$ & ${ }^{98} \mathrm{Tc}$ & $1.45 \times 10^{-5}$ \\
${ }^{202} \mathrm{~Pb}$ & & ${ }^{99} \mathrm{Tc}$ & 22.8 \\
${ }^{205} \mathrm{~Pb}$ & $1.77 \times 10^{-19}$ & ${ }^{121 \mathrm{~m}} \mathrm{Te}$ & $1.95 \times 10^{-6}$ \\
${ }^{107} \mathrm{Pd}$ & 0.243 & ${ }^{123} \mathrm{Te}$ & 0.00 \\
${ }^{208} \mathrm{Po}$ & $2.48 \times 10^{-16}$ & ${ }^{123 \mathrm{~m}} \mathrm{Te}$ & $5.60 \times 10^{-4}$ \\
${ }^{209} \mathrm{Po}$ & $3.00 \times 10^{-14}$ & ${ }^{127 \mathrm{~m}} \mathrm{Te}$ & 0.0240 \\
${ }^{210} \mathrm{Po}$ & $2.61 \times 10^{-7}$ & ${ }^{130} \mathrm{Te}$ & 0.00 \\
${ }^{190} \mathrm{Pt}$ & & ${ }^{204} \mathrm{Tl}$ & \\
${ }^{83} \mathrm{Rb}$ & $3.35 \times 10^{-9}$ & ${ }^{65} \mathrm{Zn}$ & $2.64 \times 10^{-7}$ \\
& $3.47 \times 10^{-5}$ & & \\
& & \\
& &
\end{tabular}

Given a $0.025-\mathrm{mRem} /$ year allocation for each of the isotopes shown in Table 3-2, a more manageable list of radionuclides was developed, as shown in Table 3-3. This table includes only those semivolatile isotopes with a calculated DF $>1$; isotopes with DFs of 1 or less do not require any control, even using the conservatively low $0.025-\mathrm{mRem} /$ year dose allocation per isotope.

Because the chemistry of an element dictates the method by which a DF is achieved, the list of isotopes in Table 3-3 can be shortened by only considering the largest required DF for any isotope of that element; for example, the cesium DF is dictated by ${ }^{137} \mathrm{Cs}$ or $4.9 \times 10^{9}$. There are three elements with required DF values $<10(<90 \%$ removal): cadmium, palladium, and tellurium. The chemistry of tellurium is similar to that of selenium; it might be argued that DF requirements for these elements and their isotopes should be considered together as should the effects of abatement processes. Palladium is not expected to form volatile species during aqueous processing, that is, no organometallic species or volatile oxides will be generated. Therefore, palladium can be dropped from further consideration. There remain eight elements, especially those with DF values greater than $10^{3}$, that need to be discussed in some detail to determine if 
the required DFs have been demonstrated in past operations or can be demonstrated through a discussion on known chemistry.

Table 3-2. Doses from the isotopes and associated releases shown in Table 3-1

\begin{tabular}{|c|c|c|c|c|c|}
\hline Isotope & $\begin{array}{l}\text { Dose, mRem for } \\
1 \mathrm{tIHM} / \text { year }\end{array}$ & $\begin{array}{c}\text { Dose, mRem } \\
\text { for } 10^{3} \text { tIHM/year }\end{array}$ & Isotope & $\begin{array}{c}\text { Dose, mRem for } \\
1 \mathrm{tIHM} / \text { year }\end{array}$ & $\begin{array}{c}\text { Dose, mRem } \\
\text { for } 10^{3} \mathrm{tIHM} / \text { year }\end{array}$ \\
\hline $\begin{array}{r}{ }^{110 \mathrm{~m}} \mathrm{Ag} \\
{ }^{195} \mathrm{Au}\end{array}$ & 0.0592 & 59.2 & $\begin{array}{l}{ }^{184 \mathrm{~m}} \mathrm{Re} \\
{ }^{187} \mathrm{Re}\end{array}$ & & \\
\hline${ }^{207} \mathrm{Bi}$ & $1.01 \times 10^{-15}$ & $1.01 \times 10^{-12}$ & ${ }^{101} \mathrm{Rh}$ & $6.36 \times 10^{-6}$ & 0.00636 \\
\hline${ }^{208} \mathrm{Bi}$ & $6.27 \times 10^{-16}$ & $6.27 \times 10^{-13}$ & ${ }^{102} \mathrm{Rh}$ & $3.79 \times 10^{-4}$ & 0.379 \\
\hline${ }^{210 \mathrm{~m}} \mathrm{Bi}$ & $2.00 \times 10^{-17}$ & $2.00 \times 10^{-14}$ & ${ }^{102 \mathrm{~m}} \mathrm{Rh}$ & 0.223 & 223 \\
\hline${ }^{109} \mathrm{Cd}$ & $1.59 \times 10^{-4}$ & 0.159 & ${ }^{106} \mathrm{Ru}$ & 760 & $7.60 \times 10^{5}$ \\
\hline${ }^{113} \mathrm{Cd}$ & $2.52 \times 10^{-14}$ & $2.52 \times 10^{-11}$ & ${ }^{125} \mathrm{Sb}$ & 239 & $2.39 \times 10^{5}$ \\
\hline${ }^{113 \mathrm{~m}} \mathrm{Cd}$ & 0.0512 & 51.2 & ${ }^{75} \mathrm{Se}$ & $4.84 \times 10^{-10}$ & $4.84 \times 10^{-7}$ \\
\hline${ }^{134} \mathrm{Cs}$ & $2.39 \times 10^{4}$ & $2.39 \times 10^{7}$ & ${ }^{79} \mathrm{Se}$ & 0.0131 & 13.1 \\
\hline${ }^{135} \mathrm{Cs}$ & 0.0541 & 54.1 & ${ }^{113} \mathrm{Sn}$ & $1.84 \times 10^{-13}$ & $1.84 \times 10^{-10}$ \\
\hline${ }^{137} \mathrm{Cs}$ & $1.23 \times 10^{5}$ & $1.23 \times 10^{8}$ & ${ }^{119 m} \mathrm{Sn}$ & 0.00147 & 1.47 \\
\hline${ }^{68} \mathrm{Ge}$ & $1.55 \times 10^{-17}$ & $1.55 \times 10^{-14}$ & ${ }^{121 \mathrm{~m}} \mathrm{Sn}$ & 0.190 & 190 \\
\hline${ }^{115} \mathrm{In}$ & $8.13 \times 10^{-13}$ & $8.13 \times 10^{-10}$ & ${ }^{123} \mathrm{Sn}$ & 0.00158 & 1.58 \\
\hline${ }^{40} \mathrm{~K}$ & $3.11 \times 10^{-7}$ & $3.11 \times 10^{-4}$ & ${ }^{97} \mathrm{Tc}$ & $3.13 \times 10^{-10}$ & $3.13 \times 10^{-7}$ \\
\hline${ }^{22} \mathrm{Na}$ & $3.87 \times 10^{-9}$ & $3.87 \times 10^{-6}$ & ${ }^{98} \mathrm{Tc}$ & $3.26 \times 10^{-5}$ & 0.0326 \\
\hline${ }^{202} \mathrm{~Pb}$ & & & ${ }^{99} \mathrm{Tc}$ & 2.36 & 2360 \\
\hline${ }^{205} \mathrm{~Pb}$ & $1.03 \times 10^{-22}$ & $1.03 \times 10^{-19}$ & ${ }^{121 \mathrm{~m}} \mathrm{Te}$ & $3.31 \times 10^{-8}$ & $3.31 \times 10^{-5}$ \\
\hline${ }^{107} \mathrm{Pd}$ & $3.50 \times 10^{-5}$ & 0.035 & ${ }^{123} \mathrm{Te}$ & 0.00 & 0.00 \\
\hline${ }^{208} \mathrm{Po}$ & $2.85 \times 10^{-22}$ & $2.85 \times 10^{-19}$ & ${ }^{123 \mathrm{~m}} \mathrm{Te}$ & $2.15 \times 10^{-6}$ & 0.00215 \\
\hline${ }^{209} \mathrm{Po}$ & $1.95 \times 10^{-16}$ & $1.95 \times 10^{-13}$ & ${ }^{127 \mathrm{~m}} \mathrm{Te}$ & $7.71 \times 10^{-5}$ & 0.0771 \\
\hline $\begin{array}{l}{ }^{210} \mathrm{Po} \\
{ }^{190} \mathrm{Pt}\end{array}$ & $8.61 \times 10^{-8}$ & $8.61 \times 10^{-5}$ & $\begin{array}{l}{ }^{130} \mathrm{Te} \\
{ }^{204} \mathrm{Tl}\end{array}$ & 0.00 & 0.00 \\
\hline${ }^{83} \mathrm{Rb}$ & $3.66 \times 10^{-11}$ & $3.66 \times 10^{-8}$ & ${ }^{65} \mathrm{Zn}$ & $1.73 \times 10^{-8}$ & $1.73 \times 10^{-5}$ \\
\hline${ }^{87} \mathrm{Rb}$ & $2.01 \times 10^{-6}$ & 0.00201 & & & \\
\hline
\end{tabular}

Table 3-3. Maximum required DFs for the isotopes shown in Table 3-2 for each isotope to yield $0.025 \mathrm{mRem}$ to the MEI. Only isotopes requiring a DF $>1$ for the $1000 \mathrm{tIHM} / \mathrm{y}$ case are shown

\begin{tabular}{|c|c|c|c|}
\hline Isotope & Required maximum DF & Isotope & Required maximum DF \\
\hline${ }^{110 \mathrm{~m}} \mathrm{Ag}$ & 2370 & ${ }^{125} \mathrm{Sb}$ & $9.56 \times 10^{6}$ \\
\hline${ }^{109} \mathrm{Cd}$ & 6.36 & ${ }^{79} \mathrm{Se}$ & 524 \\
\hline${ }^{134} \mathrm{Cs}$ & $9.56 \times 10^{8}$ & ${ }^{119 \mathrm{~m}} \mathrm{Sn}$ & 58.8 \\
\hline${ }^{135} \mathrm{Cs}$ & 2160 & ${ }^{121 \mathrm{~m}} \mathrm{Sn}$ & $\mathbf{7 6 0 0}$ \\
\hline${ }^{137} \mathrm{Cs}$ & $\mathbf{4 . 9 2} \times \mathbf{1 0}^{\mathbf{9}}$ & ${ }^{123} \mathrm{Sn}$ & 63.2 \\
\hline${ }^{107} \mathrm{Pd}$ & 1.4 & ${ }^{98} \mathrm{Tc}$ & 1.3 \\
\hline${ }^{102} \mathrm{Rh}$ & 15.2 & ${ }^{99} \mathrm{Tc}$ & $\mathbf{9 . 4 4} \times \mathbf{1 0}^{4}$ \\
\hline${ }^{102 \mathrm{~m}} \mathrm{Rh}$ & $\mathbf{8 9 2 0}$ & ${ }^{127 \mathrm{~m}} \mathrm{Te}$ & 3.08 \\
\hline${ }^{106} \mathrm{Ru}$ & $3.04 \times 10^{7}$ & & \\
\hline
\end{tabular}




\section{CHEMISTRY OF THE ELEMENTS POTENTIALLY REQUIRING CONTROL}

Of the potentially semivolatile elements for the isotopes shown in Table 3-3, only eight need further consideration because of their high maximum potential DFs: Ag, Cs, Rh, Ru, Sb, Se (includes Te), Sn, and Tc. While selenium and tellurium have different chemistries, the differences are small (Cotton and Wilkinson 1980), especially at these low concentrations. In the following sections, the chemical behavior of each of these elements is discussed in the context of the expected chemistry in a reprocessing facility and the likelihood that each will form volatile species.

\subsection{Silver}

Silver is formed as a fission product and is present in the silver (Ag)-loaded zeolite used for the removal of iodine from the process off-gas streams. The silver from the Ag-loaded zeolite is expected to have a different pathway through the reprocessing facility than fission product silver, but the two streams might join at the vitrification process. The total fission product ${ }^{110 \mathrm{~m}} \mathrm{Ag}$ produced in 1 year is about $1.5 \mu \mathrm{g}$. If the two processes are joined at the vitrification process, the dilution is likely to be on the order of $1 \mathrm{~kg}$ inactive silver to $1.5 \mu \mathrm{g}^{110 \mathrm{~m}} \mathrm{Ag}$ for a dilution factor of $10^{9}$. Consequently, the required maximum DF of 2370 would be achieved by isotopic dilution. Little information is found in the literature on the volatilization of silver from borosilicate glasses. In one article on the dissolution of filaments in glasses, Kessinger et al. (2001) determined that the silver was present at the surface as $\mathrm{Ag}^{0}$ if the glass is produced under slightly reducing conditions, as is usually the case in the formation of nuclear waste glasses, for processing reasons. Hence, it is expected that silver would be present in the glass in the metallic state and volatilize as such. The vapor pressures are expected to be close to $1 \mathrm{mPa}$ (Kessinger et al. 2001). These low vapor pressures were found for glasses with very high silver contents by waste glass standards, about $7 \mathrm{~mol} \%$. The low silver contents in nuclear waste glasses lower the expected vapor pressures by several orders of magnitude, further reducing the likelihood that releases of ${ }^{110 \mathrm{~m}} \mathrm{Ag}$ would exceed the maximum, consistent with the DF of 2370.

Silver is not expected to form volatile organometallic species under reprocessing conditions. Very few volatile compounds involving silver are found in the literature, and those that are require unusual chemistries not found in a reprocessing facility.

The formation of $\mathrm{AgH}$ is energetically favored by $-240 \mathrm{~kJ} / \mathrm{mol}$. However, it is expected to react with the surrounding water, be trapped in $\mathrm{NaOH}$ traps, react with $\mathrm{O}_{2}$ in air (Musil et al. 2012), or be trapped in the iodine traps.

It is concluded that the control of silver beyond what would be provided by abatement technologies typically installed in a reprocessing facility is not needed.

\subsection{Cadmium}

Cadmium has a potential maximum DF requirement of about 6, assuming all of the ${ }^{109} \mathrm{Cd}$ isotope present in the irradiated fuel is released. Although this is a very conservative assumption, the potential release of cadmium in a reprocessing plant is considered for completeness.

Volatile cadmium species have been found under moderate environmental conditions, such as gases emitted from sewers and landfills (Feldmann and Hirner 1995). Under more aggressive conditions, naturally emitted cadmium is found in the gases from fumaroles, hot springs, and wet lands in Yellowstone National Park (Planer-Friedrich and Merkel 2006) and in other aqueous media (Feng et al. 2003). The behavior of cadmium in glass melts is also known, but little is written about the volatility. In some cases, the volatility cannot be measured because the amount in the feed is relatively low and the 
releases were below the detection limits (Soelberg et al. 1997). Most information pertaining to the volatility of cadmium is found in the volcanology literature (Norman et al. 2004, Moune et al. 2006, Keller et al. 2008, Jenner and O'Neill 2012, Johnson and Canil 2011, Mather et al. 2012). With the exception of the work by Norman et al (2004) and a few other authors, the volatility is measured by examining the solidified magma and, so, the cadmium losses are somewhat qualitative. The volatility of cadmium appears to increase as the melt becomes more reducing (Khan et al. 2006).

The form of cadmium that volatilizes from a glass or magmatic melt does not appear to be discussed in the literature, but the DF for the glass melt alone would exceed a value of 6 [see Goles et al. (1981) for typical DF values for nuclear glass melts].

Cadmium does appear to form a hydride that is volatile (Valdes-Hevia y Temprano et al. 1993). However, its fate after being generated, presumably during the dissolution of fuel if nascent hydrogen is present, is not well known.

Although there is a significant amount of uncertainty with respect to the generation of volatile cadmium species, the required DF is low. The anticipated ability to achieve an adequate level of decontamination in systems used for abatement of other gaseous and particulate species (caustic scrubbing and HEPA filtration) in combination with the low probability that it is volatilized in significant proportions, lead to the conclusion that no cadmium-specific control is necessary.

\subsection{Cesium}

The high maximum potential DF for cesium means that only $2 \times 10^{-10}$ of it can be released. This means that out of the approximately $1.5 \mathrm{~kg}$ that enters a 1000 -tIHM/year facility only $0.3 \mu \mathrm{g}$ can be released each year. This is a very high bar. For example, in one hypothetical case, if $0.001 \%$ of the cesium is allowed into the off-gas stream at each of the head-end, dissolver, and solvent extraction processes and only $10 \%$ of the remaining cesium is allowed into the off-gas at the vitrification step, then a DF at the vitrification off-gas must be on the order of $5 \times 10^{5}$ with DFs at the other off-gas streams of $1 \times 10^{6}$. A $10 \%$ split to the off-gas above a glass melter is conservatively high in most cases. Burger and Scheele (2004) showed that the dominant thermodynamically favored species is $\mathrm{Cs}_{2} \mathrm{Cl}_{2}$ with a very low vapor pressure. In their assessment, cesium is removed with the installed off-gas treatment systems. Furthermore, the limits of detection for isotopes of cesium appear to be a few tenths of a $\mathrm{mBq} / \mathrm{m}^{3}$ in air. The level expected from the required overall facility DF for ${ }^{137} \mathrm{Cs}$ is about $5 \mathrm{~Bq} / \mathrm{m}^{3}$. Therefore, while the maximum potential DF appears to be very high, it can be achieved and verification of the removal can be measured. Thus, the DF values needed to achieve regulatory release of cesium appear to be achievable with HEPA filters alone at the vitrification process. Wet scrubbers and other off-gas treatment are normally included in most nuclear facilities. These provide additional DF for the removal of cesium. Therefore, particulate and aerosol forms of cesium need not be considered further.

Cesium does not form volatile species under the chemistries associated with typical aqueous reprocessing steps, except for waste vitrification. Virtually all of the cesium released to the off-gas streams is as particulates, except at the vitrification process, where it is volatilized as an oxide or possibly molybdate. These are easily condensed to particulates and are removed with scrubbers and HEPA filters. However, very little is reported on the amount of cesium volatilized in any of the other process steps and even less is reported on the amount of cesium removed in scrubbers and HEPA filters relative to the amount entering the various parts of the process.

\subsection{Rhodium}

Volatile rhodium compounds exist, but the complexity of the organo-Rh compounds suggest that they are unlikely to occur in aqueous dissolution or tritium pretreatment of oxide fuels. The exception might be the 
formation of volatile rhodium compounds with $\beta$-ketones, for example, acetone or free radicals with a similar chemistry that might be formed from radiolysis of process organics (Berg and Hartlage 1966). Rhodium hydride can form if nascent hydrogen is present, and this might occur if metallic fuel is dissolved in an aqueous acid under conditions where $\mathrm{H}_{2}$ is formed. Work has been conducted on the formation of metal hydrides for detection in analytical instruments like inductively coupled mass spectroscopy (Moor et al. 2000). These molecules are unlikely to survive transit through an aqueous scrubber or HEPA filter.

If volatile organo-Rh compounds do form, their control is likely needed in the spent organics treatment processes. In this section of the reprocessing facility, the off-gas is treated with an aqueous scrubber and HEPA filtration. Any organo-Rh that might be formed would need to be sufficiently volatile at the highest operating temperature (organic destruction) where air is present to react to form $\mathrm{RhO}_{2}$. If formed, the $\mathrm{RhO}_{2}$ particles would be easily removed from the off-gas at DF values exceeding those shown in Table 3-3.

The conclusion is that even if rhodium volatiles might occur in a reprocessing facility they should be easily captured at levels exceeding the maximum DF values shown in Table 3-3. Thus, under most conditions (with the processing of metallic fuel being a possible exception), a dedicated rhodium capture system would not be required.

\subsection{Ruthenium}

Semivolatile ruthenium compounds do exist under the conditions of an aqueous chemistry-based process. Notably, Ru-nitrosylnitrates [RuNO$\left(\mathrm{NO}_{3}\right)_{\mathrm{x}}\left(\mathrm{NO}_{2}\right)_{\mathrm{y}}(\mathrm{OH})_{3-\mathrm{x}-\mathrm{y}}\left(\mathrm{H}_{2} \mathrm{O}\right)_{2}, \mathrm{x}>1$ ] are known semivolatiles that occur during the nitric acid dissolution of oxide fuels (Brown 1960, Cains and Barnes 1991, Fletcher 1958, Fletcher et al. 1955, Maya 1979, Maya 1981, Natarajan et al. 2013, Singh et al. 2014, Swain et al. 2013, Wallace 1964, Wallace and Propst 1969, Blasius et al. 1981, Blasius et al. 1984, Blasius and Mueller 1984).

Ruthenium forms volatile oxides at vitrification temperatures (Anderson et al. 1994, Bancroft et al. 1961, Cobb and Hrma 1991, Demin et al. 1995, Gong et al. 2009, Gosse et al. 2010, Gruenewald et al. 2008, Jouan 1969, Kelley 1975, Krause and Luckschieter 1991, Ortins De Bettencourt 1969a, 1969b, Weisenburger and Weiss 1980, Wilds 1979) and are readily treated (Lawson et al. 2010, Natarajan et al. 2013, Oh et al. 1997, Shin and Park 2003).

Once the ruthenium is volatilized, the compounds have a propensity to condense on the ductwork between process equipment, for example, between the fuel dissolver and the first scrubber (Backman et al. 2005, Floquet et al. 2008, Sakurai et al. 1985, Swider-Lyons et al. 2005). While this effect adds to the overall DF for ruthenium, it causes an additional problem in that as the quantity of deposited ruthenium increases so also does the heat generation and dose contributions in the ductwork. The equilibrium partial pressure of these volatile compounds also means that ruthenium compounds migrate during the times when the processes are idle.

It appears that the ruthenium is ultimately converted to particulates that are relatively easily removed from the off-gas stream in the normally installed train of scrubbers, condensers, rough filters, and HEPA filters. This is consistent with the observations of Goles et al. (1981), who observed that the ruthenium concentration in the off-gas stream following the main off-gas scrubber and caustic scrubber sampler solution was below the detection limit of the analytical systems used. Ruthenium was observed in particulates collected on a $0.4 \mu \mathrm{m}$ membrane filter. The mean particle diameter was $0.13 \mu \mathrm{m}$.

The HEPA filters have DFs of $10^{6}$ for particulates and the scrubbers and condensers bring the DF to the required $3 \times 10^{7}$. Despite the documented volatile species for ruthenium, these species appear to be manageable with existing off-gas treatment facilities to meet regulatory releases from a reprocessing 
facility. However, the fact that ruthenium species react and condense on the stainless steel ductwork is a concern for operation of the facility and may necessitate a ruthenium-specific removal technology.

\subsection{Antimony}

There are two types of volatile antimony compounds of concern in a reprocessing facility. Antimony hydride (stibene, $\mathrm{SbH}_{3}$ ) is a gas at ambient conditions with a boiling point of $17^{\circ} \mathrm{C}$ (Stock and Doht 1902). Stibine was synthesized and characterized by Stock and coworkers (Stock and Bodenstein 1907, Stock and Doht 1901, Stock and Doht 1902, Stock et al. 1907, Stock and Guttmann 1904, Stock and Wrede 1908). Trimethyl and triethyl antimony $\left[\mathrm{Sb}\left(\mathrm{CH}_{3}\right)_{3}\right.$ and $\left.\mathrm{Sb}\left(\mathrm{C}_{2} \mathrm{H}_{5}\right)_{3}\right]$ are also gases at ambient conditions. Trimethly antimony is typically found at landfills and composts (Diaz-Bone et al. 2011, Feldmann 2003, Filella 2010, Jenkins 2002, Jenkins 2011, Kosters et al. 2003, Long and Sackman 1955). They do not react readily with water under aerobic and anaerobic conditions (Filella 2010, Jenkins 2002). All three methylated species - monomethyl, dimethyl, and trimethyl antimony - have been observed. Triethyl antimony appears to have a weaker Sb-C bond than trimethyl antimony (Skulan et al. 2006) and has not been reported at landfills and composts.

Stibine decomposes autocatalytically with the decomposition product antimony serving as the catalyst (Stock and Bodenstein 1907, Stock et al. 1907, Stock and Guttmann 1904). It also reacts with air or water. However, the decomposition appears to be slow. Strachan (1978) showed that $\mathrm{SbH}_{3}$ likely passed through the scrubbers and HEPA filters at the Hanford PUREX facility to the silver reactors where it reacted with $\mathrm{AgI}$ or $\mathrm{AgCl}$ to most likely form antimony, $\mathrm{HCl}$ or $\mathrm{HI}$, and silver (based on current knowledge). It should be noted that metallic uranium fuel was processed at Hanford.

The fact that $\mathrm{SbH}_{3}$ appeared to be transported though several gas absorbers and HEPA filters in PUREX suggests that it is a volatile of concern, and the methylated and ethylated volatiles might behave similarly. While the results from Strachan (1978) suggest that $\mathrm{SbH}_{3}$ would be removed in the iodine removal bed, the behavior on the bed has not been investigated. Likewise, $\mathrm{Sb}\left(\mathrm{CH}_{3}\right)_{3}$ and $\mathrm{Sb}\left(\mathrm{C}_{2} \mathrm{H}_{5}\right)_{3}$, which form in the organic phase or when the aqueous phase is in contact with the organic phase, might be expected to be transported to the iodine removal media before being converted to an immobile phase. The presence of $\mathrm{SbH}_{3}$ in process off-gases is only expected when metallic fuels are dissolved, since the formation of $\mathrm{SbH}_{3}$ appears to require the presence of nascent hydrogen.

The high maximum DF from Table 3-3 for ${ }^{125} \mathrm{Sb}$ suggests that further work on the volatile species $\mathrm{SbH}_{3}$, $\mathrm{Sb}\left(\mathrm{CH}_{3}\right)_{3}$, and $\mathrm{Sb}\left(\mathrm{C}_{2} \mathrm{H}_{5}\right)_{3}$ is needed to ensure regulatory releases are met for this isotope.

\subsection{Selenium and Tellurium}

Like antimony, selenium and tellurium form hydride $\left(\mathrm{H}_{2} \mathrm{Se}\right.$ and $\left.\mathrm{H}_{2} \mathrm{Te}\right)$ and dimethyl $\left[\mathrm{Se}\left(\mathrm{CH}_{3}\right)_{2}\right]$ volatile compounds. Additionally, diethyl compounds $\left[\mathrm{Se}\left(\mathrm{C}_{2} \mathrm{H}_{5}\right)_{2}\right.$ and $\left.\mathrm{Te}\left(\mathrm{C}_{2} \mathrm{H}_{5}\right)_{2}\right]$ are more readily formed and appear to be thermodynamically stable. The dimethyl-dichalcogen $\left[\mathrm{Se}_{2}\left(\mathrm{CH}_{3}\right)_{2}\right.$ and $\left.\mathrm{Se}_{2}\left(\mathrm{C}_{2} \mathrm{H}_{5}\right)_{2}\right]$ and diethyl-dichalcogen $\left[\mathrm{Se}_{2}\left(\mathrm{C}_{2} \mathrm{H}_{5}\right)_{2}\right.$ and $\left.\mathrm{Te}_{2}\left(\mathrm{C}_{2} \mathrm{H}_{5}\right)_{2}\right]$ species also exist (Srivastava et al. 1999, Winkel et al. 2010). All of these are gases at ambient temperatures (Robinson and Scott 1932). Additionally, selenium and tellurium form dimethyl and diethyl haloids $\left[\mathrm{X}_{2} \mathrm{Se}\left(\mathrm{CH}_{3}\right)_{2}, \mathrm{X}_{2} \mathrm{Se}\left(\mathrm{C}_{2} \mathrm{H}_{5}\right)_{2}, \mathrm{X}_{2} \mathrm{Te}\left(\mathrm{CH}_{3}\right)_{2}\right.$, and $\mathrm{X}_{2} \mathrm{Te}\left(\mathrm{C}_{2} \mathrm{H}_{5}\right)_{2}$ where $\mathrm{X}=\mathrm{Cl}, \mathrm{Br}$, or I] and sulfur compounds (Chan and Einstein 1972, Srivastava et al. 1999; Vernon 1920a, Vernon 1920b). This complicates the chemistry of selenium and tellurium with respect to the semivolatile species in a reprocessing facility.

Both selenium and tellurium form these volatile species at landfills and composts (Burra et al. 2010, DiazBone et al. 2011, Fatoki 1997, Feldmann 2003, Ollivier et al. 2008), in soils (Blanc and Jones 1979, Zhang and Frankenberger 2002), and marine environments (Ollivier et al. 2008). The selenium volatiles appear to be stable in concentrated $\mathrm{HNO}_{3}$ (Winkel et al. 2010). Dimethyl diselenide is highly soluble in 
water and appears to decompose rapidly to $\mathrm{Se}\left(\mathrm{CH}_{3}\right)_{2}$ (Zhang and Frankenberger 2002); presumably the same happens to $\mathrm{Te}_{2}\left(\mathrm{CH}_{3}\right)_{2}$. The dimethyl-chalcogen haloids react with silver and, presumably, would react with silver on the iodine removal media. One complicating factor is that there are two forms of the haloids where the ligand arrangement can be cis or trans (Chan and Einstein 1972); each has a different chemistry.

With respect to the chemistry in a reprocessing facility, the conditions are not very favorable for the formation of any of these compounds. However, no effort, at least no reported effort, has been made to determine their presence in parts of the facility other than the vitrification process. Above the glass melt, selenium and tellurium are found in tests with Hanford wastes (Burger and Scheele 2004, Goles et al. 1990, Goles and Schmidt 1992). While $\mathrm{SeO}_{2}$ is expected to be volatile at melt temperatures, $\mathrm{TeO}_{2}$ is not (Burger and Scheele 2004); it is likely carried along with the selenium because of the very low concentrations. However, Goles et al. (1981) found that tellurium did volatilize from the glass melt based on a comparison of elemental (isotopic) ratios. Selenium and tellurium remaining with the waste going into the vitrification process should behave similarly to sulfur and be dissolved in the glass matrix. Much effort has been expended in the design of the glass composition to avoid problems with sulfur release from the glass melt. In general, the waste loading or the amount of sulfur in the waste is lowered to avoid second phase formation and sulfur volatilization. Hence, due to the glass formulations designed to retain sulfur, any selenium and tellurium that enter the glass melter would also be retained in the glass matrix.

\subsection{Tin}

Tin and antimony are expected to have similar chemistries. Mention of $\mathrm{SnH}_{4}$ is made in context with the volatile antimony, selenium, and cadmium compounds (Filella 2010; Gunn and Green 1961; ValdesHevia y Temprano et al. 1993). Just as with antimony compounds, the methyl and ethyl tin compounds are found in the gases from landfills, composts, sewage, and like environments (Bjoern et al. 2011, Challenger 1945, Fatoki 1997, Feldmann 2003, Filella 2010; Kosters et al. 2003, Mitra et al. 2005). Volatile tin compounds are also described in literature in which chemical vapor deposition is investigated.

The presence of radiation and organics means that it is possible for methyl and ethyl free radicals to be formed. Therefore, the presence of organo-tin compounds is possible, but the concentrations depend on the G-value for their formation (the G-value is the number of molecules produced per $100 \mathrm{eV}$ of ionizing radiation absorbed). If formed, these volatile species are expected to pass unabated through HEPA filters and possibly scrubbers but be decomposed on the iodine removal media.

Given the uncertainty that these volatile species will be formed to any great extent and the relatively low DF needed to ensure compliance with the regulations for release of the three tin isotopes, the presence of volatile tin compounds is assumed to be relatively low. It is further assumed that all off-gas streams will be treated for iodine removal and that the associated DF when coupled with the release rate should exceed that shown in Table 3-3.

\subsection{Technetium}

Technetium is another element with a relatively high maximum DF (Table 3-3). However, there has been much effort expended on controlling this volatile element, especially for glass melters (Bibler et al. 2000, Ebert et al. 1998, Kim and Schweiger 2013, Lukens et al. 2007, McCloy et al. 2012, Saito et al. 2004, Schreiber et al. 2005, Soderquist et al. 2014, Vida 1989). Technetium forms a volatile oxide $\mathrm{Tc}_{2} \mathrm{O}_{7}$. It does not appear to form volatile organometallic compounds consistent with the typical aqueous processing of nuclear fuel. 
Pertechnetic acid $\left(\mathrm{HTcO}_{4}\right)$ has a substantial vapor pressure of $1.7 \mathrm{mmHg}$ at $25^{\circ} \mathrm{C}$ and $23.9 \mathrm{mmHg}$ at $75^{\circ} \mathrm{C}$, and it is stable in water and acid solutions (Bostick 2010). The potential that it may form and escape the hot dissolver solution may warrant further investigation (i.e., its vapor-liquid equilibria).

\subsection{A General Source of Radionuclides in the Off-Gas - Aerosols and Particulates}

Herrmann et al. (1980) report that the air used for stirring various solutions is the major source of aerosols found in the vessel off-gas system. They claim that the majority of the off-gas volume in a reprocessing plant is not from reaction gases generated within the process but the air used for stirring, fluid transfer, and pulsing operations. The off-gas ratio for the dissolver off-gas to vessel off-gas to the cell off-gas is reported to be 1:10:100. They point out that aerosols occur in virtually every reprocessing step. These aerosols can entrain fission products such as ${ }^{144} \mathrm{Ce},{ }^{134} \mathrm{Cs},{ }^{137} \mathrm{Cs},{ }^{90} \mathrm{Sr},{ }^{106} \mathrm{Ru}$, and ${ }^{124} \mathrm{Sb}$ as well as the transuranic elements.

The analysis by Herrmann, et al. (1980) points to two methods for aerosol generation. The first results from gas bubbles traveling through the liquid and bursting. The resulting aerosol content is approximately $10 \mathrm{mg} / \mathrm{m}^{3}$. The second aerosol source term occurs when the gas flows over the surface of the liquid, such as what occurs in pulsed columns. The aerosol content in these cases is 0.1 to $1.0 \mathrm{mg} / \mathrm{m}^{3}$.

Table 4-1 provides an example of the aerosol loading in the vessel off gas.

Table 4-1. Aerosol contributions to the vessel off-gas from vessels in the first cycle solvent extraction system (Herrmann et al. 1980)

\begin{tabular}{|l|c|c|}
\hline \multicolumn{1}{|c|}{ Aerosol source } & Air flow, $\mathbf{~ m}^{\mathbf{3}} \mathbf{/ s}$ & Air aerosol loading, $\mathbf{~} \mathbf{g} / \mathbf{m}^{\mathbf{3}}$ \\
\hline Stirring air & $0.12-0.83$ & 10 \\
\hline Transfer air (e.g., air lifts) & $0.04-0.06$ & 10 \\
\hline Pulse air & 0.17 & 0.1 \\
\hline Scavenging air & 0.04 & $0.1-1.0$ \\
\hline
\end{tabular}

Studies conducted in Japan by Fujine et al. (1996) with simulated process solutions explored the generation of aerosols due to air sparging from submerged nozzles in slab tanks and the aerosol contribution from fluid transfer operations with airlifts. The tank was also equipped with a condenser on the off-gas line. Three types of simulant solutions were examined:

$$
\begin{aligned}
& \mathrm{NaNO}_{3}+\mathrm{LiNO}_{3}(100 \mathrm{~g} / \mathrm{L}) \text { in water, } \\
& \mathrm{NaNO}_{3}+\mathrm{LiNO}_{3}(350 \mathrm{~g} / \mathrm{L}) \text { in } 3 \mathrm{M} \mathrm{HNO} \text {, and } \\
& \mathrm{NaNO}_{3}+\mathrm{LiNO}_{3} \text { in water }(100 \mathrm{~g} / \mathrm{L}) \text { with } 100 \mathrm{ppm} \text { TBP added. }
\end{aligned}
$$

They drew the following conclusions from their experiments.

1. The aerosol concentration in the off-gas from the slab tank was observed to be in the range of

$<20 \mathrm{mg} / \mathrm{m}^{3}$ with off-gas flow rates ranging from 2 to $10 \mathrm{~m} / \mathrm{s}$ and with mixing air rates up to $50 \mathrm{~m}^{3} / \mathrm{hr}$ per $\mathrm{m}^{2}$ of liquid free surface $\left(\mathrm{m}^{3} / \mathrm{hr} \cdot \mathrm{m}^{2}\right)$.

2. The aerosol concentration in the off-gas stream was roughly proportional to the mixing air flow rate.

3. Aerosol concentrations were $<10 \mathrm{mg} / \mathrm{m}^{3}$ with mixing air rates $<30 \mathrm{~m} / \mathrm{hr} \cdot / \mathrm{m}^{2}$ for the high concentration salt solution. 
4. Trace amounts of TBP, which decrease the liquid surface tension, increased aerosol concentration by a factor of 2 to 5 .

5. Aerosol concentrations after the air-liquid separation in the head pot ranged from a few to several hundred $\mathrm{mg} / \mathrm{m}^{3}$.

6. Aerosol concentrations increased with increasing temperature. In addition, more particles of a smaller size distribution were also observed at higher temperatures.

7. During evaporation in the slab tank with sweep air and evaporation rates of approximately $10 \%$ per hour, aerosol concentrations of $<10 \mathrm{mg} / \mathrm{m}^{3}$ in the off-gas stream from the condenser located on the off-gas line from the slab tank were observed.

Hanson and Kaser (1976) present some useful information on the off-gas composition and flow rates for a projected large-scale high-level waste (HLW) vitrification facility. They indicate that a 1500 -tIHM/year reprocessing facility would produce approximately $378 \mathrm{~L} / \mathrm{tIHM}$ of HLW concentrate from waste stream evaporation. This is $5.67 \times 10^{5} \mathrm{~L}$ of HLW per year. Assuming an operating time of $300 \mathrm{~d} /$ year, the processing rate of this HLW feed to the melter is approximately $80 \mathrm{~L} / \mathrm{hr}$. With these rates, the off-gas flow rate from the melter would be approximately $0.083 \mathrm{~m}^{3} / \mathrm{s}$ at $350^{\circ} \mathrm{C}$. In the case of direct heating of the melter, the approximate composition of this gas stream is $49 \% \mathrm{~N}_{2}, 35 \% \mathrm{H}_{2} \mathrm{O}, 15.2 \% \mathrm{O}_{2}, 0.1 \% \mathrm{~N}_{2} \mathrm{O}$, and $<0.1 \% \mathrm{NO}_{\mathrm{x}}$, excluding fission products. In addition to these species, small amounts of fission products may be volatilized or entrained as particulate or aerosols. The fission products identified include $\mathrm{Ru}, \mathrm{I}$, $\mathrm{Cs}, \mathrm{Te}$, and Se. They estimate that approximately $2 \%$ of the iodine in the original fuel reports to the HLW.

Johnson et al. (1998) examined the release factor for the 242-A evaporator located at the Hanford site. This evaporator was installed to reduce the volume of waste in the underground tanks and would be expected to have aerosols as the main component in the off-gas. Since 1994 a number of campaigns have been conducted, reducing the volume of waste by millions of liters. During one of the campaigns, the loading of ${ }^{137} \mathrm{Cs}$ on the primary and secondary HEPA filters was measured. By comparing the change in loading on the filter and the quantity of material processed, a release factor of $1.5 \times 10^{-12}$ for ${ }^{137} \mathrm{Cs}$ was determined. This value is for the evaporator and the demister combined and supports the conclusion that existing off-gas systems have DFs sufficient to meet those required in Table 3-3.

\section{ASSESSMENT OF THE IMPACT OF SEMIVOLATILES IN A REPROCESSING FACILITY}

In this section, results from reprocessing facilities and research directly connected to reprocessing of fuel are discussed.

\subsection{Head-End Experience with Semivolatiles}

\subsubsection{Air/Oxygen Low-Temperature $\left(480-600^{\circ} \mathrm{C}\right)$ Tritium Pretreatment}

The objective of the standard tritium pretreatment process is to remove tritium from the fuel prior to dissolution. To do so, the $\mathrm{UO}_{2}$ in the fuel is reacted with oxygen to form $\mathrm{U}_{3} \mathrm{O}_{8}$. This results in a restructuring of the crystalline $\mathrm{UO}_{2}$ accompanied by particle crumbling and the release of most of the ${ }^{3} \mathrm{H}$, significant fractions of krypton, xenon, and carbon, and a very small fraction of the iodine. The voloxidation process usually takes place at $480^{\circ} \mathrm{C}$ to $600^{\circ} \mathrm{C}$. Higher temperatures increase the reaction rate and associated release rate of the volatile species.

It is known that iodine is chemically bonded with cesium and possibly other species, preventing it from being completely released in standard voloxidation. The iodine-containing forms are minerals such as 
cesium iodide and cesium uranates (Cubicciotti and Sanecki 1978). The thermal decomposition of cesium iodide begins around $670^{\circ} \mathrm{C}$ (Kulikov and Malyshev 1983), and cesium uranates are stable at temperatures greater than $630^{\circ} \mathrm{C}$. For example, $\mathrm{Cs}_{2} \mathrm{UO}_{4}$ is stable under dry air up to around $950^{\circ} \mathrm{C}$ but will decompose at $630^{\circ} \mathrm{C}\left(2 \mathrm{Cs}_{2} \mathrm{UO}_{4} \rightarrow \mathrm{Cs}_{2} \mathrm{U}_{2} \mathrm{O}_{7}+\mathrm{Cs}_{2} \mathrm{O}\right)$ in humid air (Cordfunke et al. 1975, Dharwadkar et al. 1983).

It has been estimated that $<0.2 \%$ of the ruthenium, antimony, and cesium would be released during standard air oxidation.

An experimental study was conducted to address concerns about ruthenium transfer and deposition occurring in the tritium pretreatment process (formerly known as voloxidation) (Klein 1977). Ruthenium tetraoxide $\left(\mathrm{RuO}_{4}\right)$ was prepared and fed to a heated steel vessel where deposition of $\mathrm{RuO}_{2}$ on the surfaces was observed at temperatures between $475 \mathrm{~K}$ and $825 \mathrm{~K}$, with dense depositions occurring at $525 \mathrm{~K}$. Deposits were reported to be very adherent.

The physical chemistry of $\mathrm{RuO}_{4}$ includes a high vapor pressure: $1.01 \mathrm{mmHg}$ at $0^{\circ} \mathrm{C}, 161.2 \mathrm{mmHg}$ at $100^{\circ} \mathrm{C}$, and a theoretical boiling point of $162^{\circ} \mathrm{C}$ but with decomposition to $\mathrm{RuO}_{2}$ and $\mathrm{O}_{2}$ occurring at about $108^{\circ} \mathrm{C}$ (Penman and Hammer, 1968, HSC Chemistry, Weast 1989). The predominance diagram (calculations performed with HSC Chemistry 5.11) indicates that decomposition occurs at the same temperature whether the atmosphere is air or air containing substantial concentrations of nitrogen dioxide $\left(\mathrm{NO}_{2}\right)$, as shown in Figure 5-1. At low oxygen concentrations and high temperatures there is a tendency for the dioxide to decompose to metal, as shown in Figure 5-2. Because ruthenium is a more noble metal than say iron, there could be a tendency for ruthenium oxide to be reduced at the surface of a free metal, leading to deposition, but that has not been modeled and should be investigated.

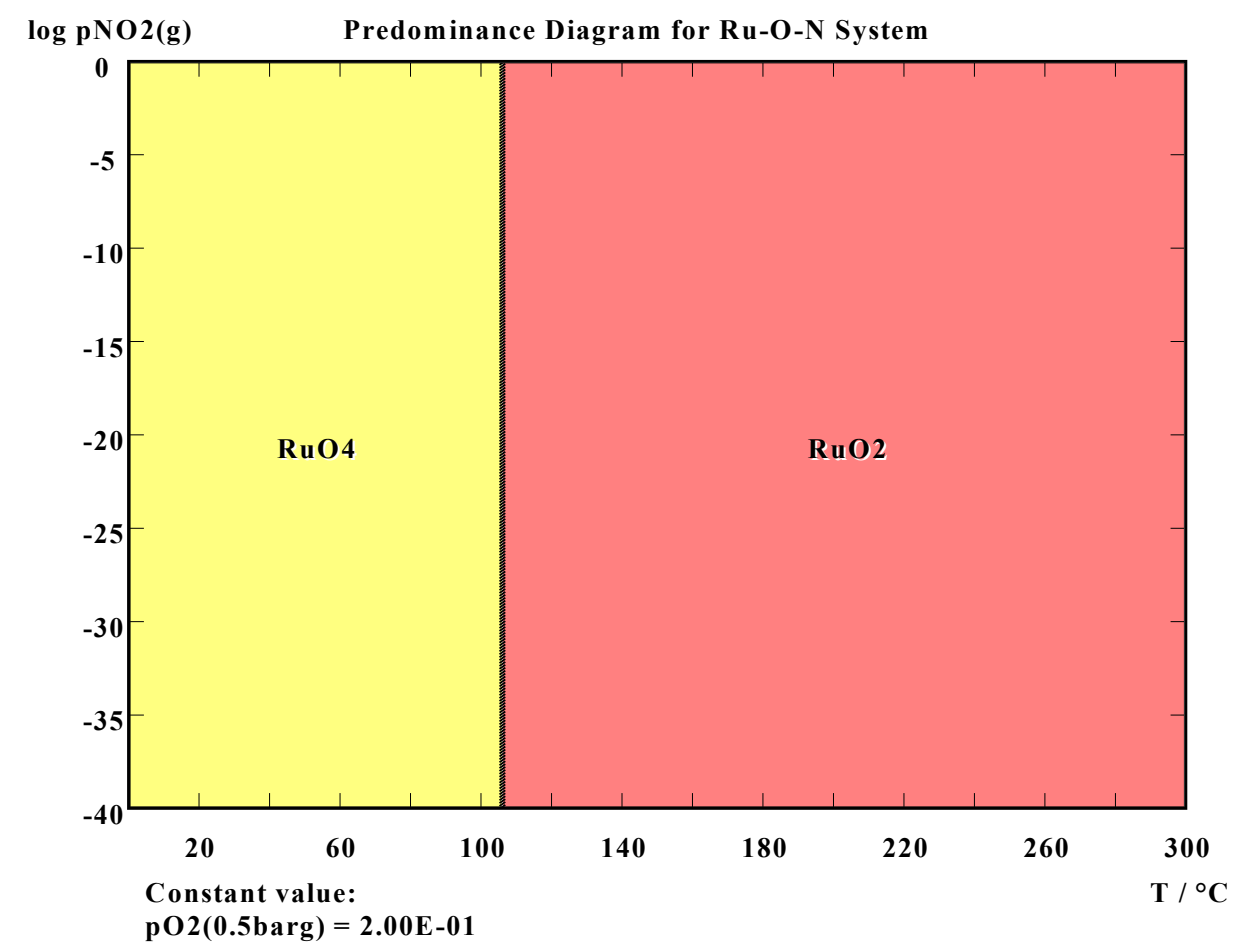

Figure 5-1. Predominance diagram for Ru-O-N system: dioxide and tetraoxide equilibria. 


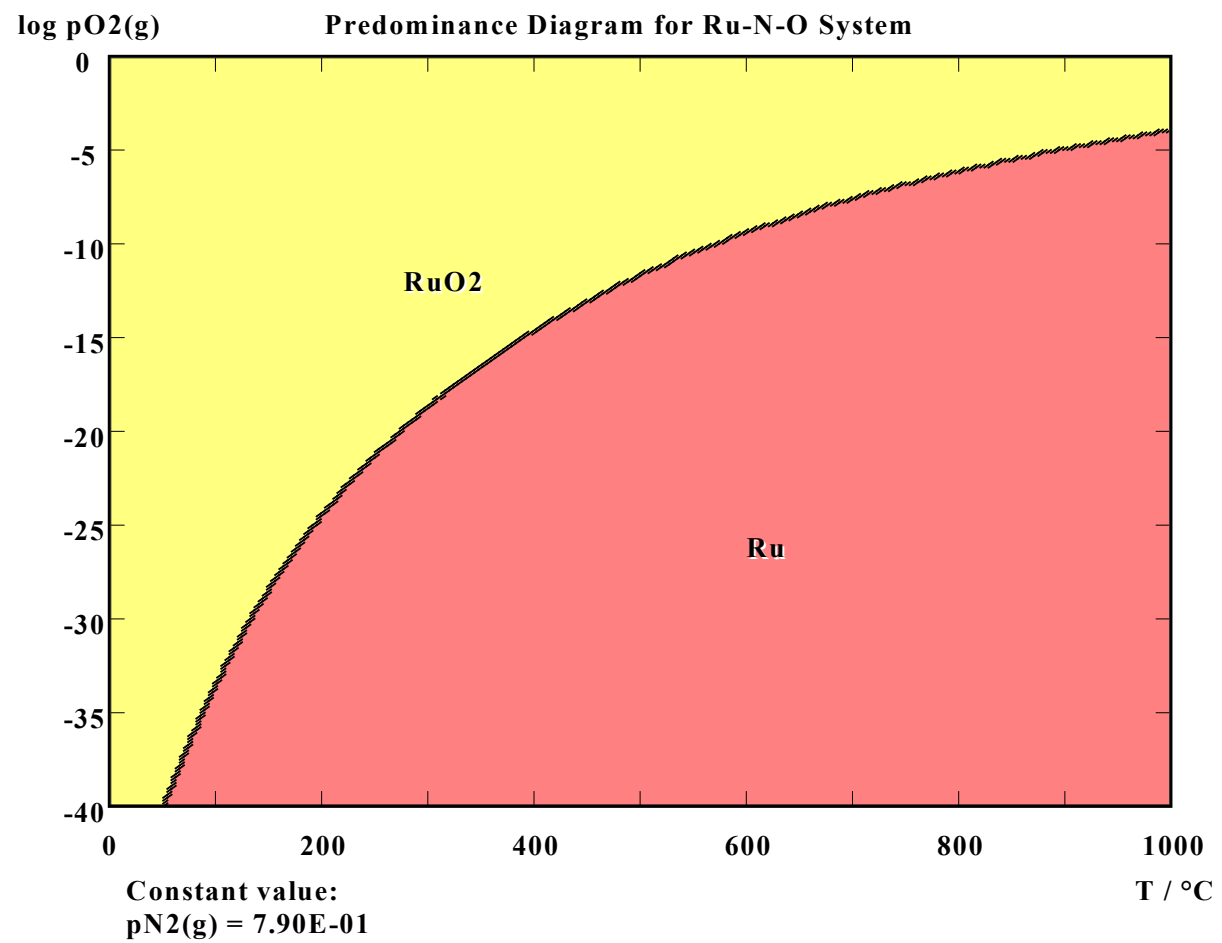

Figure 5-2. Predominance diagram for Ru-O-N system: metal and dioxide equilibria.

Considering both the deposition data and the chemistry, ruthenium may transport as either $\mathrm{RuO}_{2}$ or $\mathrm{RuO}_{4}$ and interact with surfaces resulting in deposition. As the deposits are difficult to remove, filtration processes will probably have to utilize one-use media.

During the coupled end-to-end (CETE) tests there was no evidence of semivolatile species reaching the off-gas capture and treatment systems.

\subsubsection{Advanced Tritium Pretreatment at Low Temperatures $\left(250-400^{\circ} \mathrm{C}\right)$}

Also under consideration for the head end of a reprocessing facility is the use of an advanced tritium pretreatment process.

Scoping studies indicate that alternative oxidants (e.g., ozone and water vapor) may improve release of selected volatile and semivolatile fission products either by further oxidizing the fuel and reducing its particle size or by producing more volatile chemical forms.

The oxidation temperature can also be reduced with $\mathrm{NO}_{2}$ as the oxidizing gas, with the added benefit that $\mathrm{NO}_{2}$ can also be used to convert the uranium oxides to uranyl nitrate in a dry process (Collins et al. 2013, 2014). Because ozone decomposes very rapidly at elevated temperatures in the presence of metal surfaces, $\mathrm{NO}_{2}$ is a preferred oxidant. The use of alternative oxidants also avoids the need for higher temperatures, and it is anticipated that these lower temperatures would also result in a reduction in the release of the semivolatile species.

Very limited data are available on the release of cesium or other semivolatiles under the various pretreatment conditions. Work at ORNL on advanced head-end processes has shown that use of ozone as an oxidant reduces, by about $200^{\circ} \mathrm{C}$, the temperature required to volatilize the cesium. 


\subsubsection{High-Temperature $\left(>900^{\circ} \mathrm{C}\right)$ Pretreatment Associated with the Direct Use of Spent PWR Fuel In CANDU (DUPIC) and Accident Conditions}

Fission product release studies, performed in support of programs assessing severe fuel damage, provide some data on high-temperature oxidation of fuel in either air or steam. Experiments were performed with fuel samples irradiated up to $33,000 \mathrm{MWd} / \mathrm{tIHM}$ in which the sample was first heated to $1100{ }^{\circ} \mathrm{C}$ in an argon atmosphere (Iglesias et al. 1986). The heating required about $100 \mathrm{~min}$, and then the oxidant was introduced. Oxidation in air for $100 \mathrm{~min}$ resulted in removal of $100 \%$ of the ruthenium and cesium. The report indicated that the ruthenium was released only by oxidation of the sample (i.e., none released under the inert atmosphere). The cesium and iodine were released in two steps; first $80 \%-90 \%$ was rapidly released while the sample was oxidizing, and the remainder was slowly released while at $1100^{\circ} \mathrm{C}$. The deposition evidence indicated cesium and iodine are released independently from the fuel and not as CsI.

Data in the literature and thermodynamic calculations, as well as recent tests (Westphal et al. 2005), indicate the feasibility of removing additional volatile and semivolatile species from spent fuel by oxidation in air at high temperatures. Treatment of fuel powder with oxygen at $900-950^{\circ} \mathrm{C}$ followed by vacuum almost completely removed technetium, ruthenium, and rhodium. Further heating under vacuum at $1050-1150^{\circ} \mathrm{C}$ removed nearly all Cs, Mo, Te, and Se. Tritium, ${ }^{14} \mathrm{C}$, I, Xe, and $\mathrm{Kr}$ were completely removed during the combined process.

In follow-on work, Westphal et al. (2007) reported on the results from a multi-year international collaboration in which the releases from the oxidation of used nuclear fuel (UNF) were examined. As part of this effort, tests were conducted at both the Korean Atomic Energy Research Institute (KAERI) and Idaho National Laboratory (INL). In the tests at INL, BR-3 (breeder reactor) oxide fuel with a burnup of $37 \mathrm{GWd} / \mathrm{tIHM}$ that had cooled for 26 years was used. Tests were conducted with the fuel heated with or without oxidative cover gas, in an atmosphere of air or oxygen. The samples were allowed to oxidize at $500^{\circ} \mathrm{C}$ to $700^{\circ} \mathrm{C}$ for 1 to $2 \mathrm{hr}$, followed in some cases with heating to temperatures of up to $1250{ }^{\circ} \mathrm{C}$ and decreased pressures. Six elements were monitored: $\mathrm{Cs}, \mathrm{Mo}, \mathrm{Rh}, \mathrm{Ru}, \mathrm{Tc}$, and Te.

Results from these tests showed that removal efficiencies increased with temperature. The primary route for removal of these six fission products was by the evaporation of volatile species following the oxidation cycle (Westphal et al. 2005). Results for the volatilization of five of the six fission products at $950^{\circ} \mathrm{C}$ were reported with and without vacuum. In all cases, vacuum improved the fission product removal, with cesium (50\% ambient; 75\% vacuum) and technetium (50\%; 98\%) showing the greatest effects. Molybdenum was the only fission product not removed under ambient pressure at $950^{\circ} \mathrm{C}$ because of the low vapor pressure of the oxide. About $10 \%$ removal for molybdenum was observed under vacuum (Westphal et al. 2005; Westphal et al. 2007).

The effect of the oxidant gas on the removal fractions from the fuel for $\mathrm{Cs}, \mathrm{Ru}, \mathrm{Te}$, and $\mathrm{Tc}$ was studied. The removal fraction for cesium and tellurium decreased with the change in the oxidant from air to $\mathrm{O}_{2}$ and the removal fraction for technetium and ruthenium increased with the same change. Westphal et al. $(2005,2007)$ suggested that the technetium and ruthenium results could be attributed to faster oxidation kinetics in $\mathrm{O}_{2}$ when compared to air, whereas the cesium and tellurium results were thought to be caused by the formation of nonvolatile, complex oxides (Westphal et al. 2005, 2007).

In summary, Westphal et al. ( 2007) concluded the following.

- Cesium, $\mathrm{Mo}, \mathrm{Rh}, \mathrm{Ru}$, and Te were shown to be either partially or completely removed during oxidation irradiated $\mathrm{UO}_{2}$ nuclear fuel.

- Increasing temperature generally increased the removal fraction because of oxide volatility.

- Cesium and molybdenum removal could be enhanced under vacuum. 
- The effect of oxidative gas on the removal of fission products increased or decreased the removal, depending on the fission product.

- Fission product removal can be increased by applying oxidant at temperatures greater than $500^{\circ} \mathrm{C}$.

\subsection{Melter and Waste Operations}

Several different melter technologies that have been used in past and existing waste vitrification processes, or could be used in future waste vitrification processes, include the liquid-fed ceramic melter (LFCM), hot-wall induction melter (HWIM), cold crucible induction melter (CCIM), hot-wall resistance melter (HWRM), and in-canister melter (ICM) (Law et al. 2013). Plasma arc melters have also been tested and used for solid waste vitrification but have not been advanced as a viable candidate for liquid/slurry HLW vitrification (Eddy 1995). The majority of partitioning data readily available to the public is for LFCMs, CCIMs, and plasma arc melters.

Volatilization and aerosol entrainment can depend significantly on the melter design, feed material, and operating conditions, as some of the data below show (Soelberg 1997). One of the most significant parameters that can affect volatilization is the melt temperature, although the effects of this dependence can be masked by other operating parameters including the use of bubblers (which can increase both volatilization and aerosol entrainment) and cold cap (which can reduce volatilization by condensing and refluxing volatilized elements back to the glass).

The CCIM technology has been included as the vitrification technology for the Case Study, in part because of its ability to operate at melt temperatures ranging up to $1400^{\circ} \mathrm{C}$ (Law 2013). Given similar feed conditions, the melting conditions for the CCIM are similar to those for the joule-heated LFCM. At Commissariat à l'énergie atomique (CEA), the CCIM would be used to produce the same glass as has been produced using a HWIM, without the need to increase the operating temperature. Given the same temperature and other melt conditions, the volatilization and aerosol entrainment would be expected to be about the same for the HWIM, CCIM, and HWRM. For cases where a CCIM might be operated to produce a glass-ceramic, which is the direction of continuing research and development, temperatures of 1200 to $1400^{\circ} \mathrm{C}$ might be needed. In those cases cesium, etc. would be expected to partition more to the gas phase.

\subsubsection{Cesium Behavior}

Oma and Nelson (1981) discussed the off-gas from a LFCM operating at temperatures as high as $1200^{\circ} \mathrm{C}$. Steady-state semivolatiles entering the off-gas system were, in mass $\%$, Cs 13; Ru 0.16; Sb 0.11; and Te 0.44 . They also indicated that volatilization accounted for 70 to 90 mass $\%$ of the elements leaving the melter; physical entrainment accounted for the remaining 10 to 30 mass $\%$.

Zamecnik et al (1992), in preparation for the startup of the Defense Waste Processing Facility (DWPF), investigated the cesium emissions experimentally using the Integrated DWPF Melter System (IDMS), a pilot-scale test facility. These emissions compared favorably with the design basis for the DWPF. The DWPF design basis and the measured values from the IDMF are shown in Table 5-1. These results indicated that less than $0.0001 \%$ of the cesium in the feed to the melter reached the HEPA filters. More than $99.9 \%$ was retained in the melter, with the Steam Atomized Scrubber and Condenser and the HighEfficiency Mist Eliminator recovering more than $99 \%$ of the cesium that was released from the melter.

Additional information on the off-gas from the DWPF melter is provided by Moeller (1991). He reports that the off-gas rate is approximately $0.19 \mathrm{~m}^{3} / \mathrm{s}(400 \mathrm{cfm})$ and contains micrometer-sized particles plus mercury, steam, and non-condensable gases. Cesium-137 and ${ }^{90} \mathrm{Sr}$ are the main radioactive components in the melter feed. Two to three percent of the ${ }^{137} \mathrm{Cs}$ volatilizes and condenses in the off-gas as $0.2-1 \mu \mathrm{m}$ aerosol particles. Strontium-90 is entrained from the melter, but the fraction entrained was not reported. 
Experience at the DWPF suggests that the needed DF for cesium is met under normal operating conditions. The analytical sensitivity is adequate to detect the quantity being released to ensure that regulatory limits are met.

Pilot-scale nonradioactive CCIM tests were performed to generate data on how a CCIM would process DWPF Sludge Batch 4 feed (Soelberg 2009). These tests were operated with the CCIM melt temperature between $1250^{\circ} \mathrm{C}$ and $1300^{\circ} \mathrm{C}$, and resulted in $10 \%$ cesium evolution to the melter off-gas $(\mathrm{DF}=10)$, when the total carryover of all solids fed was $0.29 \%$ and the carryover of iron (a known very nonvolatile element) was only $0.03 \%$. Cesium, under these test conditions, is about 300 times more volatile than iron.

Table 5-1. Design and measured cesium decontamination factors (Zamecnik et al. 1992)

\begin{tabular}{|l|l|l|}
\hline \multicolumn{1}{|c|}{ Process } & DWPF design DF & IDMS measured DF \\
\hline Melter & 15 & 132 \\
\hline Quencher / Off-gas condensate tank & $<8.9$ & 2.7 \\
\hline Steam Atomized Scrubber / Condenser & 50 & 28.5 \\
\hline High-Efficiency Mist Eliminator & 40 & 314 \\
\hline Overall before HEPA filters & $2.67 \times 10^{5}$ & $3.19 \times 10^{6}$ \\
\hline HEPA Filter \#1 & 422 & $1^{a}$ \\
\hline HEPA Filter \#2 & 24.5 & $\mathrm{NA}$ \\
\hline Overall after HEPA filters & $2.76 \times 10^{9}$ & $3.19 \times 10^{6}$ \\
\hline
\end{tabular}

${ }^{a}$ This value was reported as 0.75 . However, that means more particles came out of the filter than went in. A value of 1 (no filtering) is assigned.

Goles et al. (1981) report results for the Nuclear Waste Vitrification Project. Results from the analyses of the particulates and the off-gases that pass through a series of scrubbers, condensers, rough filters, and HEPA filters showed less than detectable $\left(<100 \mathrm{nCi} / \mathrm{m}^{3}\right)$ emissions at the stack. Particulates were collected separately on a more sensitive filter and measured. Results indicated that about $60 \%$ of the particulates were $0.2 \mu \mathrm{m}$ or smaller. In a later report, essentially the same results were obtained for a ceramic melter (Goles and Sevigny 1983). In the studies conducted by Goles and Sevigny (1983) on the off-gas from liquid-fed joule-heated ceramic melters, they found that particles were responsible for most melter losses. A significant fraction of the particulate mass in the off-gas system was in the form of submicrometer aerosol particles.

Cesium partitioning to the CCIM off-gas in the case study was estimated at 10\% (DF = 10) (Law 2013) based on results of extensive measurements on Hanford low-activity waste vitrification using a LFCM at similar operating conditions (Soelberg 2009). Evolution of volatilized and entrained matter to the off-gas downstream of the melter is reduced in this design by recycling a portion of the off-gas wet scrub solution back to the melter, thereby reducing the cesium evolution in the scrubber outlet gas to about $0.01 \%$ of the cesium input to the melter $\left(\sim 10^{4}\right.$ combined melter-scrubber DF).

\subsubsection{Ruthenium Behavior}

At the Idaho Chemical Processing Plant (ICPP) new calcining facility, Christian (1990) reported that 22 to $62 \%$ of the ruthenium was volatilized during calcination. The higher value occurred during the burning of the kerosene diluent used in the extraction process. The most likely volatile form was a nitrato or oxyfluoride specie. Silica gel beds were used to retain the ruthenium. A procedure for cleaning the off-gas lines was also described. This involved an initial contact with $4 \mathrm{M} \mathrm{HNO}_{3}$, followed by $6 \mathrm{M} \mathrm{HNO}_{3}$ at $80^{\circ} \mathrm{C}$ or $10 \mathrm{M} \mathrm{HNO}_{3}$ at $60^{\circ} \mathrm{C}$. 
Studies in Japan at the Ishikawajima Harima Heavy Industries Co (Kitamura et al. 1993) were conducted with a simulated waste solution. In these studies, the overall performance of an aqueous scrub system was examined. The results showed that a DF of 100 was achievable for a variety of conditions.

Vujisić and Nikolić (1983) discuss the adsorption of gaseous $\mathrm{RuO}_{4}$ on impregnated Alcoa alumina $\mathrm{H} 151$ impregnated charcoal and silica gel. Tests were conducted at $25^{\circ} \mathrm{C}, 60 \%$ relative humidity, and a residence time of $0.3 \mathrm{~s}$. In these tests it was shown that silica gel retained between 97.3 and $99.9 \%$ of the volatilized ruthenium. They also pointed out that the rapid reduction to $\mathrm{RuO}_{2}$ and the associated liberation of oxygen may have interfered with the subsequent performance of the sorbent, and recommended that the sorbent be chosen such that the reduction proceeds slowly.

Rimshaw and Case (1981) studied various simulated high-level nitrate waste streams that been denitrated with formic acid. The use of formic acid avoided the production of $\mathrm{NO}$ and $\mathrm{NO}_{2}$ but did produce $\mathrm{N}_{2} \mathrm{O}$. The use of formic acid also significantly reduced the volatilization of $\mathrm{RuO}_{4}$. Tests conducted on an untreated acidic thorium nitrate waste at temperatures between 250 and $300^{\circ} \mathrm{C}$ resulted in the volatilization of 26.2 and $27.5 \%$ of the ruthenium, respectively. When the same waste was pretreated with 2.0 moles of formic acid per mole of nitrate, the percent volatilized was reduced to 0.07 and $0.15 \%$, respectively.

Hanson and Kaser (1976) report that the ruthenium volatility varies widely and is a function of the process, the product, and the operating conditions. In the case of borosilicate glass production with spray calcination and in-canister melting, less than $2 \%$ of the ruthenium should be volatilized based on experience at the Waste Solidification Engineering Prototypes (WSEP) program conducted at Hanford in the late 1960s and early1970s. Cesium losses from volatilization ranged from 0.002 to $0.07 \%$ of the cesium in the HLW. In addition to these specific volatile species, it should be expected that particulates would be entrained and contain a mixture of all of the fission products contained in the feed to the melter. They estimate that the particulate fraction is $\sim 0.001$ of mass of the feed to the melter.

Table 5-2 provides an estimate of the activity of the major fission products entering the off-gas systems from the filters on the calciner/melter system assuming processing $1500 \mathrm{t}$ of PWR fuel with a burnup of 33,000 MWd/tIHM (Hanson and Kaser 1976). The activity in the feed to the melter is based on time of discharge. The iodine activity in the waste is $2 \%$ of iodine in the incoming fuel and the processing rate for the melter is 300 days/year. While the activity, especially for iodine, is very high due to using activity at discharge, the release fractions would remain the same for any age fuel.

Table 5-2. Melter release fractions

\begin{tabular}{|c|c|c|c|}
\hline \multirow{2}{*}{ Element/isotope } & \multicolumn{3}{|c|}{ Activity, Ci/hr } \\
\cline { 2 - 4 } & Melter off-gas $^{\boldsymbol{a}}$ & Melter feed $^{\boldsymbol{b}, \boldsymbol{c}}$ & Fraction released $^{-1}$ \\
\hline Iodine & $4.95 \times 10^{4}$ & $4.95 \times 10^{4 d}$ & 1.00 \\
\hline Ruthenium & $7.85 \times 10^{3}$ & $1.08 \times 10^{6}$ & 0.0073 \\
\hline Cesium & $1.04 \times 10^{3}$ & $1.64 \times 10^{6}$ & 0.0006 \\
\hline Particulate & $2.43 \times 10^{4}$ & $3.58 \times 10^{7}$ & 0.0007 \\
\hline
\end{tabular}

${ }^{a}$ Based on Table II of Hanson and Kaser (1976)

${ }^{b}$ Basis 1500 t of PWR fuel with $33000 \mathrm{MWd} / \mathrm{tIHM}$ burnup at discharge

${ }^{c}$ Melter processing 300 days/year, $24 \mathrm{hr} /$ day

${ }^{d} \%$ in iodine in discharged fuel 
Another interesting comment made by Hanson and Kaser (1976) is that when considering the release limits for the facility, the effluents from the solidification process should only be considered to represent $10 \%$ of the allowable limit.

A single-pass melter DF of 67 is used for ruthenium in the case study design (Law 2013). After recycling a portion of the wet scrub solution back to the melter, the combined DF is increased to about $6.4 \times 10^{4}$.

\subsubsection{Antimony}

Antimony is also a volatile element from glass melters (Beerkens and Van Limpt 1998, Burger and Scheele 2004, Goles et al. 1981). An antimony DF of 5 is used in the case study design (Law 2013). However, the volatilizing species is $\mathrm{Sb}_{2} \mathrm{O}_{5}$ readily condenses to a particulate and is easily trapped in the scrubbers and HEPA filters (Burger and Scheele 2004), and none was found in the stack gases from the Nuclear Waste Vitrification Project (Goles et al. 1981). Evolution of volatilized and entrained matter to the off-gas downstream of the melter is reduced in the case study design by recycling a portion of the offgas wet scrub solution back to the melter, thereby reducing the antimony evolution in the scrubber outlet gas so that the combined melter-scrubber DF is about $2.6 \times 10^{4}$.

Not all of the antimony is volatilized during vitrification. The partitioning should result in a combined DF sufficient to remove the antimony below regulatory releases.

\subsubsection{Tellurium and Selenium}

Goles et al. (1981) found that tellurium did volatilize from the glass melt based on a comparison of elemental (isotopic) ratios. A DF of 5 is used in the case study design (Law 2013) for both tellurium and selenium. After recycling a portion of the wet scrub solution back to the melter, the combined DF is increased to about 5800 for tellurium and 7700 for selenium.

\subsubsection{Technetium}

Rimshaw and Case (1981) reported that less than $1 \%$ of the ${ }^{99} \mathrm{Tc}$ is volatilized during the calcining of either alkaline or acidic nitrate solutions.

Technetium volatilization is expected to occur primarily in the glass melter. Bibler et al. (2000) showed that less than $10 \%$ of the cesium and the technetium was lost from the glass during 2.5 years of waste processing at the Savannah River Site DWPF. In tests conducted in a small melter without a cold cap $\sim 30 \%$ of the technetium was lost. The much lower technetium losses in the DWPF melter were attributed to the presence of the cold cap in the DWPF melter. For the technetium that is lost to the off-gas system, decontamination factors exceeding that required for technetium (Table 3-3) are typical for HEPA filters $\left[\approx 10^{6}(\right.$ IAEA 2014)].

A single-pass melter DF of only 2.5 is used for technetium in the case study design (Law 2013). After recycling a portion of the wet scrub solution back to the melter, the combined DF is increased to about $2.6 \times 10^{4}$.

\subsubsection{Comparison of Releases between CCIM and JHMM}

Gruber et al. (2011) provide some limited data on the characterization the off-gas from a Joule-heated metal melter (JHMM) and a CCIM. The data were collected over a period of 10 years and are presented in terms of melter DFs based on the feed to the melter compared to the amount of that element found in the off-gas capture /treatment system. Table 5-3 provides a comparison of the system DF.

This table shows that cesium, ruthenium, and tellurium tend to be retained to the same extent by a JHMM or CCIM vitrification system, even though these two technologies differ in a number of process 
parameters. This included the glass production capacity $(25 \mathrm{~kg} / \mathrm{hr}$ for the JHMM vs. $36 \mathrm{~kg} / \mathrm{hr}$ for the $\mathrm{CCIM})$, processing temperature $\left(1110^{\circ} \mathrm{C}\right.$ for the $\mathrm{JHMM}$ vs. $1200^{\circ} \mathrm{C}$ for the $\left.\mathrm{CCIM}\right)$, and bubbling and sweeping rate (4-5 vs $8-10 \mathrm{Nm}^{3} / \mathrm{h}$ ) for the JHMM vs CCIM, respectively.

Table 5-3. Melter DFs for selected semi-volatile species (Gruber et. al. 2011)

\begin{tabular}{|c|c|c|}
\hline & JHMM & CCIM \\
\hline Ruthenium & 100 & 65 \\
\hline Cesium & 28 & 50 \\
\hline Tellurium & 65 & 43 \\
\hline
\end{tabular}

They concluded that the CCIM with a higher molten glass temperature had a contamination control performance comparable to the JHMM and would have no impact on the off-gas treatment system even with the associated higher temperature and gas rate.

The CCIM test for DWPF Sludge Batch 4 waste did not include surrogates for the semivolatile metals other than cesium included in this study (Soelberg 2009). However, partitioning measurements were made for some other elements in the feed known to have semivolatile behavior, including potassium, sulfur, and zinc. Figure 5-1 shows the melter partitioning data for the elements that were in the surrogate feed. The behavior of the potassium, sulfur, and zinc could be generally indicative of some of the potentially semivolatile elements in this study. Figure 5-3 shows the melter partitioning data for the elements that were in the surrogate feed. The DFs for potassium, sulfur, and zinc were $50(2 \%$ to the melter off-gas), 16 (6.3\% to the melter off-gas), and 6 (17\% to the melter off-gas), respectively.

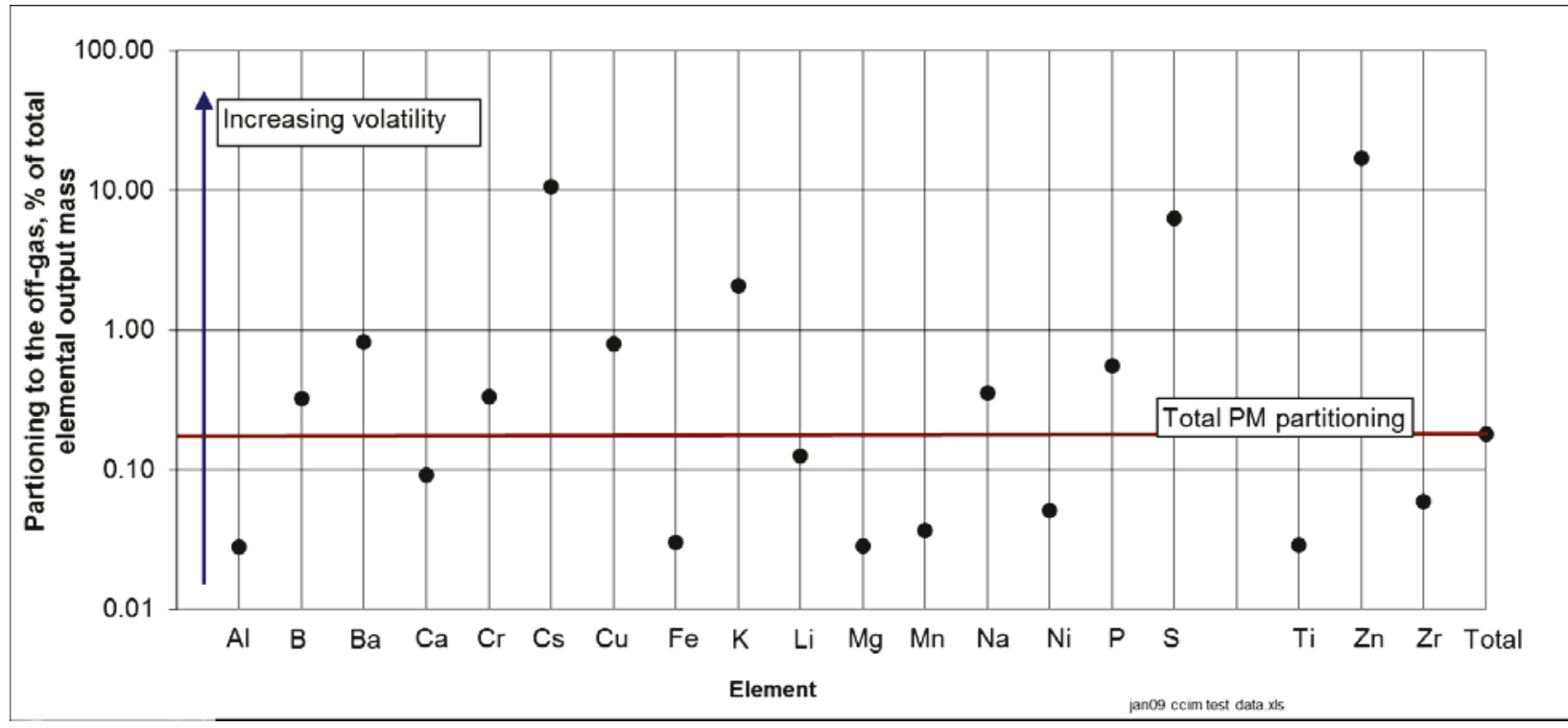

Figure 5-3. Melter partitioning data from a pilot-scale CCIM test for DWPF Sludge Batch 4 surrogate feed (Soelberg 2009).

Off-gas control efficiencies for the metals shown here that can be achieved by a high performance off-gas control system can in some cases be at least as high as can be proven with measurements (Soelberg 2001). When multiple off-gas control technologies are used in series (such as a wet scrubber followed by highefficiency mist eliminator, reheater, multiple HEPA filtration, and iodine sorbent bed), the overall DFs can reach $10^{9}$ or higher. In some cases, actual measurements for operating systems may not reach such high DFs due to resolution/detection limits of available analytical instruments and methods. 


\subsection{Storage Tanks}

At the CEA, the behavior of Ru in the waste tanks was examined with respect to the consequences of a failure in a high level waste tank. Of concern was the fraction of Ru that could be released in a volatile or aerosol form. Philippe et al. (1990) state that previous studies showed the following:

- Solution concentrations in nitric acid and nitrates: while the effect of nitrates is less well understood, the volatility of Ru in nitric acid generally becomes high for acid concentrations between 8 and $13 \mathrm{M}$, with volatile $\mathrm{RuO}_{4}$ being formed by oxidation of the Ru nitrosyl complexes in solution.

- The presence of reducing agents: these products inhibit or delay the formation of RuO. They may be formed by radiolysis of the medium $\left(\mathrm{HNO}_{2}, \mathrm{H}_{2} \mathrm{O}_{2}\right.$, etc.), or introduced in the different steps of the process (tributyl phosphate entrained in raffinates, denitration with formic acid).

- Solution storage time: the equilibrium of the different chemical species of Ru present in the concentrates is often slow to be established, and depends on the age of the solution. Storage also influences radiolysis in solution (production yield of certain species, degradation rate of organic compounds).

- Temperature: during evaporation, the oxidation kinetics of the Ru complexes depends directly on the temperature profile. At higher temperatures, thermal decomposition of the Ru nitrosyl complexes may also cause the formation of volatile $\mathrm{RuO}_{4}$.

However, it was concluded that the number of parameters involved made it improbable that the behavior of ruthenium could be easily calculated. Thus, Philippe et al. undertook an experimental measurement with actual fission product concentrates to determine the losses as the solution was taken to dryness. Results from this test indicated that ruthenium is only volatilized just as the solution reaches dryness, and the total amount of ruthenium released was approximately $15 \%$ at $160^{\circ} \mathrm{C}$. The volatilized ruthenium recombined in the presence of $\mathrm{H}_{2} \mathrm{O}, \mathrm{HNO}_{3}, \mathrm{NO}_{\mathrm{x}}$ and $\mathrm{O}_{2}$ as ruthenium oxide on the walls of the test apparatus. They also identified three distinct phases for the ruthenium release:

1. the boiling phase - a slight transfer of ruthenium from the tank, occurring by aerosol entrainment,

2. the phase approaching dryness - ruthenium begins to oxidize and volatilization predominates over transfer by aerosol entrainment, and

3. the final dryness or calcine phase - volatilization of $\mathrm{RuO}_{4}$ that decomposed on the tank walls or reacted with $\mathrm{NO}_{\mathrm{x}}$ to form $\mathrm{RuO}_{2}$.

\section{CONCLUSIONS}

As a term, "semivolatile" is not clearly defined, so it is not given a specific definition in this document. To compensate for this lack definition, a broad list of the isotopes that could become volatile by reaction with other compounds under certain conditions in the reprocessing plant is considered. This list comes from an ORIGEN code in SCALE (Gauld et al. 2011, ORNL 2009) calculation for UNF with $60 \mathrm{GWd} / \mathrm{tIHM}$ burnup and 5 years of cooling. Each radionuclide in this long list is assumed to be the only radionuclide in the off-gas - a conservative case - and is used in an airborne radiological dispersion and risk assessment code CAP-88 (Rosnick 2007) calculation for the resulting dose to the MEI. An assessment of these doses leads to a shorter list of eight isotopes of concern. Each of the elements represented by these isotopes is discussed with respect to its overall volatility and then evaluated as to the likelihood that a volatile compound would be formed and escape through the various off-gas treatments to the stack gases and give rise to a potential regulatory violation. The context for this evaluation is a 
$\mathrm{UO}_{2}$-based fuel processed through an aqueous-based reprocessing system with a TBP-based solvent extraction chemistry. None of these elements form sufficiently volatile compounds in the context of the reprocessing facility to be of regulatory concern from an emission standpoint based on volatility alone and taking into account current or proposed use of scrubbers and particulate filtration technology. Deposition of certain semivolatile compounds on surfaces within the off-gas system is however likely.

\section{REFERENCES}

Anderson, LD, T Dennis, ML Elliott, and P Hrma. 1994. "Noble Metal Behavior During Melting of Simulated High-Level Nuclear Waste Glass Feeds." Ceram. Trans. 39 (Environmental and Waste Management Issues in the Ceramic Industry):265-72.

Backman, U, M Lipponen, A Auvinen, U Tapper, R Zilliacus, and JK Jokiniemi. 2005. "On the Transport and Speciation of Ruthenium in High Temperature Oxidising Conditions." Radiochimica Acta 93(5):297304. 10.1524/ract.93.5.297.64280.

Bancroft, AR, LC Watson, and CW Hoelke. 1961. "Volatilization and Collection of Ruthenium and Cesium in a System for Incorporating Fission Products into Glass." At. Energy Can. Ltd., [Rep.] AECL AECL-1233:42 pp.

Beerkens, RGC and J Van Limpt. 1998. Volatilization in Glass Furnaces. In Proceedings of the Melting Processes in Glass Furnaces, Proceedings of the HVG/NCNG Colloquium, 51-61 pp. Verlag der Deutschen Glastechnischen Gesellschaft, Frankfurt/Main, Germany.

Berg, EW and FR Hartlage, Jr. 1966. "Fractional Sublimation of Various Metal B-Diketone Chelates." Anal. Chim. Acta 34(1):46-52.

Bibler, NE, TL Fellinger, SL Marra, RJ O'Driscoll, JW Ray, and WT Boyce. 2000. "Tc-99 and Cs-137 Volatility from the DWPF Production Melter During Vitrification of the First Macrobatch of HLW Sludge at the Savannah River Site." Mater. Res. Soc. Symp. Proc. 608(Scientific Basis for Nuclear Waste Management XXIII):697-702.

Bjoern, A, M Hoersing, J Ejlertsson, and BH Svensson. 2011. "Transformation of Methyltin Chlorides and Stannic Chloride under Simulated Landfill Conditions." Waste Manage. Res. 29(12):1327-36. $10.1177 / 0734242 X 10397088$.

Blanc, O and LP Jones. 1979. "Production of Dimethyl Tellurium by the Soil Fungus, Penicillium-SP." Texas Journal of Science 31(4):378-79.

Blasius, E, JP Glatz, and W Neumann. 1981. "Ruthenium Nitrosyl Complexes in Radioactive Waste Solutions of Reprocessing Plants. I. Cationic Ruthenium Nitrosyl Complexes." Radiochim. Acta 29(23):159-66.

Blasius, E, HJ Luxenburger, and W Neumann. 1984. "Ruthenium Nitrosyl Complexes in Radioactive Waste Solutions of Reprocessing Plants. II. Ruthenium Nitrosyl Complexes in High-Level Wastes." Radiochim. Acta 36(3):149-53.

Blasius, E and K Mueller. 1984. "Ruthenium Nitrosyl Complexes in Radioactive Waste Solutions of Reprocessing Plants. III. Behavior of Ruthenium Nitrosyl Complexes During Storage, Concentration and Calcination." Radiochim. Acta 37(4):217-22.

Bostick, WD. 2010. "Chemical and Radiological Properties Affecting The Control of Tc-99 Contamination during K-25 and K-27 D\&D Activities," Materials and Chemistry Laboratory, Inc., March. 
Brown, PGM. 1960. "Nitro Complexes of Nitrosylruthenium." Journal of Inorganic and Nuclear Chemistry 13(1-2):73-83. http://dx.doi.org/10.1016/0022-1902(60)80238-2.

Burger, LL and RD Scheele. 2004. HWVP Iodine Trap Evaluation. Report No. PNNL-14860, Pacific Northwest National Laboratory, Richland, WA.

Burra, R, GA Pradenas, RA Montes, CC Vasquez, and TG Chasteen. 2010. "Production of Dimethyl Triselenide and Dimethyl Diselenenyl Sulfide in the Headspace of Metalloid-Resistant Bacillus Species Grown in the Presence of Selenium Oxyanions." Analytical Biochemistry 396(2):217-22. 10.1016/j.ab.2009.09.026.

Cains, PW and SJ Barnes. 1991. "Deposition of Volatilized Ruthenium on Stainless-Steels." Journal of Nuclear Materials 186(1):83-86. 10.1016/0022-3115(91)90356-c.

Challenger, F. 1945. "Biological Methylation." Chemical Reviews 36(3):315-61. 10.1021/cr60115a003.

Chan, LYY and FW Einstein. 1972. "Crystal and Molecular Structure of Alpha-diIodo(Dimethyl)Tellurium." Journal of the Chemical Society-Dalton Transactions (3):316. $10.1039 / \mathrm{dt} 9720000316$.

Christian, JD. 1990. Behavior and Control of Ruthenium During Operation of the New Waste Calcining Facility at the Idaho Chemical Processing Plant. In Proceedings of the $21^{\text {st }}$ DOE/NRC Nuclear Air Cleaning Conference, 467-87 pp. The Harvard Air Cleaning Laboratory, Cambridge, MA.

Cobb, WT and P Hrma. 1991. "Behavior of Ruthenium(IV) Oxide in a Glass Melt." Ceram. Trans. 23(Nucl. Waste Manage. 4):233-7.

Collins, ED, GD DelCul, RD Hunt, JA Johnson, and BB Spencer. 2014. "Advanced Dry Head-End Reprocessing of Light Water Reactor Spent Nuclear Fuel." US Patent No. 8,747,790.

Collins, ED, GD DelCul, RD Hunt, JA Johnson, and BB Spencer. 2013. "Advanced Dry Head-End Reprocessing of Light Water Reactor Spent Nuclear Fuel." US Patent No. 8,574,523.

Cordfunke, EHP, AB Van Egmond, and G Van Voorst. 1975. "Cesium Uranates. I. Characterization of the Phases in the Cesium-Uranium-Oxygen System." J. Inorg. Nucl. Chem. 37(6):1433-6. 10.1016/00221902(75)80785-8.

Cotton, FA and G Wilkinson. 1980. Advanced Inorganic Chemistry: A Comprehensive Text. Fourth ed., John Wiley and Sons, New York, New York.

Cubicciotti, D and JE Sanecki. 1978. "Characterization of Deposits on inside Surfaces of LWR Cladding." J. Nucl. Mater. 78(1):96-111. 10.1016/0022-3115(78)90508-1.

DeHart, MD and SM Bowman. 2011. "Reactor Physics Methods and Analysis Capabilities in SCALE." Nuclear Technology 174(2):196-213.

Demin, AV, YI Matyunin, and MI Fedorova. 1995. Noble Metal (NM) Behavior during Simulated HLLW Vitrification in Induction Melter with Cold Crucible. In Proceedings 443-45 pp. American Society of Mechanical Engineers,

Dharwadkar, SR, M Shyamala, G Chattopadhyay, and MS Chandrasekharaiah. 1983. "Thermal Stability of Cesium Uranate (Cs2uo4) Phase at High Temperature." Trans. Indian Inst. Met. 36(4-5):295-7. 
Diaz-Bone, RA, M Raabe, S Awissus, B Keuter, B Menzel, K Kueppers, R Widmann, and AV Hirner. 2011. "Investigation of Biomethylation of Arsenic and Tellurium During Composting." J. Hazard. Mater. 189(3):653-59. 10.1016/j.jhazmat.2010.12.011.

Ebert, WL, AJ Bakel, DL Bowers, EC Buck, and JW Emery. 1998. "The Incorporation of Technetium into a Representative Low-Activity Waste Glass." Ceram. Trans. 87(Environmental Issues and Waste Management Technologies in the Ceramic and Nuclear Industries III):431-40.

Eddy, TL, NR Soelberg, and BR Raivo. 1995."Plasma/Arc Melter Review for Vitrification of Mixed Wastes: Results," International Symposium on Environmental Technologies, Plasma Systems and Applications, Atlanta, GA, October 8-11.

EPA. 2010. Protection of Environment: Chapter I--Environmental Protection Agency (Continued). Part 190_Environmental Radiation Protection Standards for Nuclear Power Operations. 40CFR190.10. US Environmental Protection Agency, Washington, DC.

Fatoki, OS. 1997. "Biomethylation in the Natural Environment: A Review." South African Journal of Science 93(8):366-70.

Feldmann, J. 2003. "Volatilization of Metals from a Landfill Site - Generation and Immobilization of Volatile Species of Tin, Antimony, Bismuth, Mercury, Arsenic, and Tellurium on a Municipal Waste Deposit in Delta, British Columbia." In Biogeochemistry of Environmentally Important Trace Elements, eds. Y Cai and OC Braids, Vol 835, pp. 128-40.

Feldmann, J and AV Hirner. 1995. "Occurrence of Volatile Metal and Metalloid Species in Landfill and Sewage Gases." Int. J. Environ. Anal. Chem. 60(2-4):339-59. 10.1080/03067319508042888.

Feng, Y-L, RE Sturgeon, and JW Lam. 2003. "Generation of Atomic and Molecular Cadmium Species from Aqueous Media." Anal. Chem. 75(3):635-40. 10.1021/ac020529+.

Filella, M. 2010. "Alkyl Derivatives of Antimony in the Environment." Met. Ions Life Sci. 7(Organometallics in Environment and Toxicology):267-301. 10.1039/9781849730822-00267.

Fletcher, JM. 1958. "Complexes Derived from (RuNO) III and Ru IV." Journal of Inorganic and Nuclear Chemistry 8(0):277-87. http://dx.doi.org/10.1016/0022-1902(58)80191-8.

Fletcher, JM, IL Jenkins, FM Lever, FS Martin, AR Powell, R Todd, NRW Benwell, PGM Brown, DF Sangster, and AG Wain. 1955. "Nitrato and Nitro Complexes of Nitrosylruthenium." J. Inorg. Nucl. Chem. 1:378-401. 10.1016/0022-1902(55)80048-6.

Floquet, S, C Eysseric, D Maurel, JM Fulconis, and J Delaorange. 2008. "Effect of Ozone on Ruthenium Species in Alkaline Medium - Part III: Oxidative Dissolution of Ruthenium Deposits onto Stainless Steel." Radiochimica Acta 96(8):497-504. 10.1524/ract.2008.1520.

Fujine, S, K Kitamura, and T Kihara. 1996. Simulation Test of Aerosol Generation from Vessels in the Pretreatment System of Fuel Reprocessing. In Proceedings of the $24^{\text {th }}$ DOE/NRC Nuclear Air Cleaning and Treatment Conference (NUREG/CP-0153, CONF-960715), 778-87 pp. The Harvard Air Cleaning Laboratory, Cambridge, MA.

Gauld, IC, G Radulescu, G Ilas, BD Murphy, ML Williams, and D Wiarda. 2011. "Isotopic Depletion and Decay Methods and Analysis Capabilities of SCALE." Nuclear Technology 174(2):169-95.

Goles, RW, FP Brauer, DC Hamilton, and JE Fager. 1981. Nuclear Waste Vitrificaiton Effluent. In Proceedings of the 16 ${ }^{\text {th }}$ DOE Nuclear Air Cleaning Conference (CONF-801038), 891-910 pp. The Harvard Air Cleaning Laboratory, Cambridge, MA. 
Goles, RW, RK Nakaoka, JM Perez, GJ Sevigny, SO Bates, MR Elmore, DE Larson, KD Wiemers, ME Perterson, CM Andersen, WC Buchmiller, and CM Ruecker. 1990. Final Technical Report, Hanford Waste Vitrification Program Pilot-Scale Ceramic Melter Test 23. Report No. PNL-7142, Pacific Northwest Laboratory, Richland, WA.

Goles, RW and AJ Schmidt. 1992. Evaluation of Liquid-Fed Ceramic Melter Off-Gas System Technologies for the Hanford Waste Vitrification Plant. Report No. PNL-8109, Pacific Northwest Laboratory, Richland, WA.

Goles, RW and GJ Sevigny. 1983. Off-Gas Characteristics of Liquid-Fed Joule-Heated Ceramic Melters. In Proceedings of Proceedings of the 17th DOE Nuclear Air Cleaning Conference (CONF-820833), 30532 pp. The Harvard Air Cleaning Laboratory, Cambridge, MA.

Gong, W, W Lutze, KS Matlack, and IL Pegg. 2009. "Testing and Modelling the Behaviour of Platinoids During Vitrification of High Level Radioactive Waste: Part 3." Glass Technol.: Eur. J. Glass Sci. Technol., Part A 50(2):95-107.

Gosse, S, S Schuller, and C Gueneau. 2010. "Thermodynamic Modelling of the Pd-Te-Ru System for Nuclear Waste Glasses Application." Mater. Res. Soc. Symp. Proc. 1265. 10.1557/PROC-1265-AA03-04.

Gruber, PE, A Tronche, V Ledoux, J-F Labe, J Hollebecque, C Lacombe, C. Ladirat, and S. Naline. 2011. "Limited Increase of Particle Entrainment in the Off-Gas System of a Cold Crucible Induction Melter Compared with a Joule-Heated Metal Melter for HLLW Vitrification," WM2011 Conference, February 28-March 3, 2011, Phoenix, AZ.

Gruenewald, W, G Roth, W Tobie, K Weiss, and S Weisenburger. 2008. "The Role of the Platinum Group Elements Ruthenium, Rhodium and Palladium in the Vitrification of Radioactive High Level Liquid Waste Using Joule Heated Ceramic Lined Waste Glass Melters." Glass Technol.: Eur. J. Glass Sci. Technol., Part A 49(6):266-78.

Gunn, SR and LG Green. 1961. "Heats of Formation of Some Unstable Gaseous Hydrides." J. Phys. Chem. 65:779-83. 10.1021/j100823a018.

Hanson, MS and JD Kaser. 1976. Design of Off-Gas Cleaning Systems for High-Level Waste Vitrification. In Proceedings of the $14^{\text {th }}$ ERDA Air Cleaning Conference (CONF-760822), 102-17 pp. US Printing Office, Washington, DC.

Herrmann, FJ, E Lang, J Furrer, and E Henrich. 1980. Some Aspects for Aerosol Production and Removal During Spent Fuel Processing Steps. Presented at the $16^{\text {th }}$ DOE Nuclear Air Cleaning Conference (CONF-801038), 623-30 pp. Department of Energy, Washington, DC.

HSC Chemistry 5.11, Outokumpu Research, Espoo, Finland.

IAEA. 2014. Treatment of Radioactive Gaseous Waste. Report No. IAEA-TECDOC-1744, International Atomic Energy Agency, Vienna, Austria.

Iglesias, FC, CEL Hunt, DS Cox, NA Keller, RD Barrand, RF O'Connor, and JR Mitchell. 1986. UO 2 Oxidation and Fission Product Release. In Proceedings of the $1^{\text {st }}$ International CNS CANDU Fuel Conference, Atomic Energy Canada Limited, Ottawa, CA.

Jenkins, RO. 2011. Biomethylation of Arsenic, Antimony and Bismuth. In Proceedings of the Conference on Biological Chemistry of Arsenic, Antimony and Bismuth, 145-80 pp. John Wiley \& Sons Ltd., Chichester, UK.

Jenkins, RO. 2002. "Microbial Biomethylation of Antimony." Trends Organomet. Chem. 4:109-22. 
Jenner, FE and HSC O'Neill. 2012. "Analysis of 60 Elements in 616 Ocean Floor Basaltic Glasses." Geochem., Geophys., Geosyst. 13(2):No pp. given, 11 pp. 10.1029/2011GC004009.

Johnson, A and D Canil. 2011. "The Degassing Behavior of Au, Tl, as, $\mathrm{Pb}, \mathrm{Re}, \mathrm{Cd}$ and Bi from Silicate Liquids: Experiments and Applications." Geochimica et Cosmochimca Acta 75(7):1773-84.

10.1016/j.gca.2010.12.023.

Johnson, RE, MW Bowman, WE Davis, RK Price, and RR Randall. 1998. Determination of the Radionuclide Release Factor for an Evaporator Process Using Nondestructive Assay. In Proceedings of the 25 ${ }^{\text {th }}$ DOE/NRC Nuclear Air Cleaning and Treatment Conference (CONF-980803), 502-13 pp. The Harvard Air Cleaning Laboratory, Cambridge, MA.

Jouan, A. 1969. Volatility of Ruthenium During Vitrification Operations on Fission Products. Part 1. Distillation of Nitric Acid Solutions. Concentration of the Calcinates. Report No. CEA-R-36631, Commissariat à l'énergie atomique et aux énergies alternatives, Bagnols-sur-Cèze, France.

Jubin, R, N Soelberg, D Strachan, and G Ilas. 2012a. Fuel Age Impacts on Gaseous Fission Product Capture During Separations. Report No. FCRD-SWF-2012-000089, PNNL-22550, Oak Ridge National Laboratory, Oak Ridge, TN.

Jubin, RT, NR Soelberg, DM Strachan, and G Ilas. 2012b. Position Paper on Practicable Performance Criteria for the Removal Efficiency of Volatile Radionuclides. Report No. FCRD-SWF-2012-000091, Oak Ridge National Laboratory, Oak Ridge, TN.

Keller, NS, RJ Arculus, J Hermann, and S Richards. 2008. "Submarine Back-Arc Lava with Arc Signature: Fonualei Spreading Center, Northeast Lau Basin, Tonga." J. Geophys. Res., [Solid Earth] 113(B8):B08S07/1-B08S07/28. 10.1029/2007JB005451.

Kelley, JA. 1975. Incorporation of Savannah River Plant Radioactive Waste into Glass. Report No. DPMS-7470, E. I. du Pont de Nemours and Co., Aiken, SC.

Kessinger, GF, T Huett, and JE Delmore. 2001. "Ag Ion Formation Mechanisms in Molten Glass Ion Emitters." Int. J. Mass Spectrom. 208(1/3):37-57. 10.1016/S1387-3806(01)00378-5.

Khan, MS, MA Khan, and MPI Qazi. 2006. "Development of Selenium Ruby Glass with Improved Techniques to Retain the Ruby Coloration." Pak. J. Sci. 58(3-4):116-20.

Kim, D and MJ Schweiger. 2013. "Incorporation and Distribution of Rhenium in a Borosilicate Glass Melt Heat Treated in a Sealed Ampoule." J. Non-Cryst. Solids 379:123-26.

10.1016/j.jnoncrysol.2013.07.031.

Kitamura, M, K Shirato, and K Arai. 1993. Experimental Study on the Volatile Ruthenium Decontamination Factor of the Perforated Plate Column Scrubber. In Proceedings of th $22^{\text {nd }}$ DOE/NRC Nuclear Air Cleaning and Treatment Conference (NUREG/CP-130, CONF-9020823), 253-61 pp. The Harvard Air Cleaning Laboratory, Cambridge, MA.

Klein, JA. 1977. Ruthenium Oxide Deposition and Scouring in a Rotary Kiln Voloxidizer, ORNL/TM5665, Oak Ridge National Laboratory, January.

Klein, M. 1991. "Retention of Semivolatiles in High-Temperature Processes." In Treatment of Gaseous Effluents at Nuclear Facilities, eds. WRA Goossens, GG Eichholz and DW Tedder, pp. 311-61. Harwood Academic Publishers, London, UK. 
Kosters, J, RA Diaz-Bone, B Planer-Friedrich, B Rothweiler, and AV Hirner. 2003. "Identification of Organic Arsenic, Tin, Antimony and Tellurium Compounds in Environmental Samples by GC-MS." Journal of Molecular Structure 661:347-56. 10.1016/j.molstruc.2003.09.005.

Krause, C and B Luckschieter. 1991. "Properties and Behavior of the Platinum Group Metals in the Glass Resulting from the Vitrification of Simulated Nuclear Fuel Reprocessing Waste." Journal of Materials Research 6(12):2535-46.

Kulikov, A and ML Malyshev. 1983. "Radiation-Chemical Decomposition of CsI." Atomnaya Energiya 55(5):316-18.

Law, J, N Soelberg, T Todd, J Tripp, C Pereira, M Williamson, W Ebert, R Jubin, B Moyer, J Vienna, G Lumetta, J Crum, T Rudisill, J Bresee, C Phillips, B Willis, P Murray, S Bader. 2013. "Separation and Waste Form Campaign Full Recycle Case Study,” FCRD-SWF-2013-000380, September 30.

Lawson, Y, CM Brookes, CJ Steele, MJ Sarsfield, and Asme. 2010. Understanding Potential Release Mechanisms of Volatile Ruthenium during the Vitrification of High Level Waste. In Proceedings of Proceedings of the 12th International Conference on Environmental Remediation and Radioactive Waste Management 2009, 859-68 pp. ASME, New York, NY.

Long, LH and JF Sackman. 1955. "Heat of Formation of Antimony Trimethyl." Trans. Faraday Soc. 51:1062-4. 10.1039/tf9555101062.

Lukens, WW, DA McKeown, AC Buechele, IS Mueller, DK Shuh, and IL Pegg. 2007. Behavior of Technetium, Rhenium, and Ruthenium in Glass Wasteforms. Report No. NUCL-155, Catholic University, Washington, DC.

Mather, TA, MLI Witt, DM Pyle, BM Quayle, A Aiuppa, E Bagnato, RS Martin, KWW Sims, M Edmonds, AJ Sutton, and E Ilyinskaya. 2012. "Halogens and Trace Metal Emissions from the Ongoing 2008 Summit Eruption of Kilauea Volcano, Hawaii." Geochim. Cosmochim. Acta 83:292-323. 10.1016/j.gca.2011.11.029.

Maya, L. 1981. "Chemistry of Extractable Nitrosyl Ruthenium Species in the System Nitric Acid-Tributyl Phosphate-Dodecane." J. Inorg. Nucl. Chem. 43(2):385-90. 10.1016/0022-1902(81)90028-2.

Maya, L. 1979. "Ruthenium(IV) in Nitric Acid Media." J. Inorg. Nucl. Chem. 41(1):67-71. 10.1016/00221902(79)80396-6.

McCloy, JS, BJ Riley, A Goel, M Liezers, MJ Schweiger, CP Rodriguez, P Hrma, D-S Kim, WW Lukens, and AA Kruger. 2012. "Rhenium Solubility in Borosilicate Nuclear Waste Glass: Implications for the Processing and Immobilization of Technetium-99." Environ. Sci. Technol. 46(22):12616-22. 10.1021/es302734y.

Mitra, SK, K Jiang, K Haas, and J Feldmann. 2005. "Municipal Landfills Exhale Newly Formed Organotins." J. Environ. Monit. 7(11):1066-68. 10.1039/b511767d.

Moeller, DW. 1991. Air Clean Technologies for the Management and Disposal of Radioactive Wastes. In Proceedings of the $21^{s t}$ DOE/NRC Nuclear Air Cleaning Conference (NUREG/CP-0116, CONF-900813), 28-41 pp. The Harvard Air Cleaning Laboratory, Cambridge, MA.

Moor, C, JWH Lam, and RE Sturgeon. 2000. "A Novel Introduction System for Hydride GenerationInductively Coupled Plasma Mass Spectrometry: Determination of Selenium in Biological Materials." J. Anal. At. Spectrom. 15(2):143-49. 10.1039/a909296j. 
Moune, S, P-J Gauthier, SR Gislason, and O Sigmarsson. 2006. "Trace Element Degassing and Enrichment in the Eruptive Plume of the 2000 Eruption of Hekla Volcano, Iceland." Geochim.

Cosmochim. Acta 70(2):461-79. 10.1016/j.gca.2005.09.011.

Musil, S, J Kratzer, M Vobecky, and T Matousek. 2012. "In Situ Collection of Volatile Silver Species in a New Modular Quartz Tube Atomizer for Atomic Absorption Spectrometry." J. Anal. At. Spectrom. 27(9):1382-90. 10.1039/c2ja30112a.

Natarajan, R, K Dhamodharan, PK Sharma, S Pugazhendi, V Vijayakumar, NK Pandey, and RVS Rao. 2013. "Optimization of Flowsheet for Scrubbing of Ruthenium During the Reprocessing of Fast Reactor Spent Fuels." Sep. Sci. Technol. (Philadelphia, PA, U. S.) 48(16):2494-98.

10.1080/01496395.2013.807828.

Norman, MD, MO Garcia, and VC Bennett. 2004. "Rhenium and Chalcophile Elements in Basaltic Glasses from Ko'olau and Moloka'i Volcanoes: Magmatic Outgassing and Composition of the Hawaiian Plume." Geochim. Cosmochim. Acta 68(18):3761-77. 10.1016/j.gca.2004.02.025.

Oh, WZ, HG Lee, GI Park, BS Choi, and KW Lee. 1997. State-of-the-Art Report on the Off-Gas Treatment Technology Generated from the Nuclear Facilities. Report No. KAERI/AR-477/97, Korea Atomic Energy Research Institute, Daejeon, South Korea.

Ollivier, PRL, AS Bahrou, S Marcus, T Cox, TM Church, and TE Hanson. 2008. "Volatilization and Precipitation of Tellurium by Aerobic, Tellurite-Resistant Marine Microbes." Appl. Environ. Microbiol. 74(23):7163-73. 10.1128/AEM.00733-08.

Oma, KH and TA Nelson. 1981. Behavior of Selected Contaminants in Liquid-Fed Ceramic Melter Waste-Vitrification Off Gas. In Proceedings of the $16^{\text {th }}$ DOE Nuclear Air Cleaning Conference (CONF801038), 911-28 pp. The Harvard Air Cleaning Laboratory, Cambridge, MA.

ORNL. 2009. SCALE: A Modular Code System for Performing Standardized Computer Analyses for Licensing Evaluations (Version 6). Report No. ORNL/TM 2005/39 Vols. I - III, Oak Ridge National Laboratory, Oak Ridge, TN.

Ortins De Bettencourt, A. 1969a. Volatility of Ruthenium During Vitrification Operations of Fission Products. Part 2 - Fixation on a Steel Tube, Decomposition of the Peroxide. Report No. CEA-R-3663PT-2, Commissariat à l'énergie atomique et aux énergies alternatives, Bagnols-sur-Cèze, France.

Ortins De Bettencourt, A. 1969b. Volatility of Ruthenium During Vitrification Operations on Fission Products. First Part - Distillation of Nitric Solutions, Calcination of Concentrates. Report No. CEA-R3663-1, Commissariat à l'énergie atomique et aux énergies alternatives, Bagnols-sur-Cèze, France.

Penman, BD and RR Hammer. 1968. "The Ruthenium Dioxide-Oxygen Ruthenium Tetroxide Equilibrium,” IN-1013, Idaho Nuclear Corporation, January.

Philippe, M, JP Mercier, and JP Gue. 1990. Behavior of Ruthenium in the Case of Shutdown of the Cooling System of HLLW Storage Tanks. In Proceedings of the $21^{\text {st }}$ DOE/NRC Nuclear Air Cleaning Conference, 831-43 pp. The Harvard Air Cleaning Laboratory, Cambridge, MA.

Planer-Friedrich, B and BJ Merkel. 2006. "Volatile Metals and Metalloids in Hydrothermal Gases." Environ. Sci. Technol. 40(10):3181-87. 10.1021/es051476r.

Rimshaw, SJ and FN Case. 1981. Volatilities of Ruthenium, Iodine, and Technetium on Calcining Fission Product Nitrate Wastes. In Proceedings of the $16^{\text {th }}$ DOE Nuclear Air Cleaning Conference (CONF801038), 838-66 pp. The Harvard Air Cleaning Laboratory, Cambridge, MA. 
Robinson, PL and WE Scott. 1932. "Some Physical Properties of the Hydrides of Selenium and Tellurium." Journal of the Chemical Society:972-79. 10.1039/jr9320000972.

Rosnick, R. 2007. CAP88-PC Version 3.0 User Guide. Report, Environmental Protection Agency, Washington, DC.

Rosnick, R. 1992. CAP-88 ( Clean Air Act Assessment Package-1988). US Environmental Protection Agency, Washington, DC.

Saito, HH, TB Calloway, Jr., DM Ferrara, AS Choi, TL White, LV Gibson, Jr., and MA Burdette. 2004. "Regulatory Off-Gas Analysis from the Evaporation of Hanford Simulated Waste Spiked with Organic Compounds." J. Air Waste Manage. Assoc. 54(10):1242-53. 10.1080/10473289.2004.10470994.

Sakurai, T, Y Hinatsu, A Takahashi, and G Fujisawa. 1985. "Adsorption of Ruthenium Tetroxide on Metal-Surfaces." Journal of Physical Chemistry 89(10):1892-96. 10.1021/j100256a016.

Schreiber, HD, CW Schreiber, and AM Swink. 2005. "Redox Activity of Rhenium in Silicate Glasses." Ceram. Trans. 168(Environmental Issues and Waste Management Technologies in the Ceramic and Nuclear Industries X):163-70.

Shin, JM and JJ Park. 2003. "Trapping Characteristics of Volatile Ruthenium Oxides by $\mathrm{Y}_{2} \mathrm{O}_{3}$ Filter." Korean Journal of Chemical Engineering 20(1):145-50. 10.1007/bf02697200.

Singh, K, NL Sonar, TP Valsala, Y Kulkarni, T Vincent, and A Kumar. 2014. "Removal of Ruthenium from High-Level Radioactive Liquid Waste Generated During Reprocessing of Spent Fuel." Desalination and Water Treatment 52(1-3):514-25. 10.1080/19443994.2013.848655.

Skulan, AJ, IMB Nielsen, CF Melius, and MD Allendorf. 2006. "BAC-MP4 Predictions of Thermochemistry for Gas-Phase Antimony Compounds in the Sb-H-C-O-Cl System." J. Phys. Chem. A 110(17):5919-28. 10.1021/jp057467m.

Soderquist, CZ, MJ Schweiger, D-S Kim, WW Lukens, and JS McCloy. 2014. "Redox-Dependent Solubility of Technetium in Low Activity Waste Glass." J. Nucl. Mater. 449(1-3):173-80. 10.1016/j.jnucmat.2014.03.008.

Soelberg, NR, DM Ginosar, GL Anderson, and WK O'Connor. 1994. "Fate of Metals and TRU Surrogates During Arc Melter Vitrification," Proceedings of the Spectrum '94 Nuclear and Hazardous Waste Management International Topical Meeting, Atlanta, GA, August 14-18, 842-47pp.

Soelberg, NR, AG Chambers, JD Grandy, KJ Liekhus, and GL Anderson. 1997. Metals, Particulate, and Radionuclide Partitioning Results from Mixed Waste Thermal Treatment Demonstrations. In Proceedings of the International Conference on Incineration and Thermal Treatment Technologies, 769-82 pp. University of California, Irvine.

Soelberg, NR. 2001. "Hazardous and Radioactive Waste Treatment Technologies Handbook," "Off-gas Control for Mixed Waste Thermal Treatment Systems," HO Chang, editor, CRC Press, Washington, D.C., May.

Soelberg, N, J Roach, M Ancho, and John Richardson. 2009. "ART CCIM Phase II-A Off-Gas System Evaluation Test Report," INL/EXT-09-15711, April.

Srivastava, PC, A Sinha, S Bajpai, HG Schmidt, and M Noltemeyer. 1999. "Dimethyl Tellurium (IV) Derivatives: Synthesis, Spectroscopic Characterisation and Structures of $\mathrm{Me}_{2} \mathrm{TeBr}_{2}$ and $\mathrm{Me}_{2} \mathrm{Te}\left(\mathrm{OCOC}_{6} \mathrm{H}_{5}\right)_{2}$." Journal of Organometallic Chemistry 575(2):261-68. 10.1016/s0022$328 x(98) 01003-1$. 
Stock, A and M Bodenstein. 1907. "On the Theory of the Decomposition of Stibine." Berichte der Deutschen Chemischen Gesellschaft 40:570-75.

Stock, A and W Doht. 1902. "About the Preparation of Stibine. [Machine Translation]." Berichte der Deutschen Chemischen Gesellschaft 35:2270-75.

Stock, A and W Doht. 1901. "The Pure Preparation of the Stibine. [Machine Translation]." Berichte der Deutschen Chemischen Gesellschaft 34(I):2339-44.

Stock, A, F Gomolka, and H Heynemann. 1907. "The Decomposition of Stibine." Berichte der Deutschen Chemischen Gesellschaft 40:532-70.

Stock, A and O Guttmann. 1904. "The Decomposition of Antimony Hydride." Berichte der Deutschen Chemischen Gesellschaft 37:901.

Stock, A and F Wrede. 1908. "The Heat of Formation of Antimony Hydride." Berichte der Deutschen Chemischen Gesellschaft 41:540-3.

Strachan, DM. 1978. Analysis of the Dissolver Silver Reactors from Hanford's Purex Plant. Report No. RHO-ST-2, Rockwell Hanford Operations, Richland, WA.

Swain, P, C Mallika, R Srinivasan, UK Mudali, and R Natarajan. 2013. "Separation and Recovery of Ruthenium: A Review." Journal of Radioanalytical and Nuclear Chemistry 298(2):781-96.

10.1007/s10967-013-2536-5.

Swider-Lyons, KE, CT Love, and DR Rolison. 2005. "Selective Vapor Deposition of Hydrous $\mathrm{RuO}_{2}$ Thin Films." Journal of the Electrochemical Society 152(3):C158-C62. 10.1149/1.1859713.

Valdes-Hevia y Temprano, MC, MR Fernandez de la Campa, and A Sanz-Medel. 1993. "Generation of Volatile Cadmium Species with Sodium Tetrahydroborate from Organized Media: Application to Cadmium Determination by Inductively Coupled Plasma Atomic Emission Spectrometry." J. Anal. At. Spectrom. 8(6):847-52.

Vernon, RH. 1920a. "Organic Derivatives of Tellurium Part I Dimethyltelluronium Dihaloids." Journal of the Chemical Society 117:86-98. 10.1039/ct9201700086.

Vernon, RH. 1920b. "Organic Derivatives of Tellurium Part II Constitution of the Dimethyltelluronium Dihaloids." Journal of the Chemical Society 117:889-98. 10.1039/ct9201700889.

Vida, J. 1989. Chemical Behavior of Technetium During Treatment of High-Level Radioactive Waste. Report, Kernforschungszentrum Karlsruhe, Karlsruhe, Germany.

Vujisić, L and R Nikolić. 1983. Adsorption of Gaseous $\mathrm{RuO}_{4}$ by Various Sorbents, II. In Proceedings of the $17^{\text {th }}$ DOE Nuclear Air Cleaning Conference., 123-30 pp. The Harvard Air Cleaning Laboratory, Cambridge, MA.

Wallace, RM. 1964. "Nitrosylruthenium-Organophosphorus Complexes." Nucl. Sci. Eng. 19(3):296-9.

Wallace, RM and RC Propst. 1969. "Studies of Ruthenium(IV) and Its Reduction Products in Perchlorate Solutions." J. Amer. Chem. Soc. 91(14):3779-85. 10.1021/ja01042a015.

Weast, RC, Ed. 1989. Handbook of Chemistry and Physics, 70 ${ }^{\text {th }}$ ed., CRC Press.

Weisenburger, S and K Weiss. 1980. "Ruthenium Volatility Behavior During HLLW Vitrification in a Liquid-Fed Ceramic Waste Melter." Sci. Basis Nucl. Waste Manage. 2:901-10. 10.1007/978-1-46843839-0 108. 
Westphal, BR, KJ Bateman, RP Lind, KL Howden, and GD Del Cul. 2005. Fission Product Removal from Spent Oxide Fuel by Head-End Processing. In Proceedings of Global 2005, Atomic Energy Society of Japan, Tokyo, Japan.

Westphal, BR, JJ Park, and GD Del Cul. 2007. "I-NERI Final Technical Report-Project 2004-004-K, Development of Voloxidation Process for Treatment of LWR Spent Fuel." Oak Ridge National Laboratory, Oak Ridge, TN.

Wilds, GW. 1979. "Volatilization from Borosilicate Glass Melts of Simulated Savannah River Plant Waste." Proc. DOE Nucl. Air Clean. Conf. 15(1):95-110.

Winkel, L, J Feldmann, and AA Meharg. 2010. "Quantitative and Qualitative Trapping of Volatile Methylated Selenium Species Entrained through Nitric Acid." Environmental Science \& Technology 44(1):382-87. 10.1021/es902345m.

Zamecnik, JR, DH Miller, and JT Carter. 1992. Measurement of Cesium Emissions During the Vitrification of Simulated High Level Radioactive Waste. In Proceedings of the $22^{\text {nd }}$ DOE/NRC Nuclear Air Cleaning and Treatment Conference, 253-61 pp. The Harvard Air Cleaning Laboratory, Cambridge, MA.

Zhang, YQ and WT Frankenberger. 2002. "Fate of Dimethyldiselenide in Soil." Journal of Environmental Quality 31(4):1124-28. 